\title{
Biochar and Its Broad Impacts in Soil Quality and Fertility, Nutrient Leaching and Crop Productivity: A Review
}

\author{
Hiba M. Alkharabsheh ${ }^{1}$, Mahmoud F. Seleiman ${ }^{2,3}{ }^{(\mathbb{D}}$, Martin Leonardo Battaglia ${ }^{4}\left(\mathbb{D}\right.$, Ashwag Shami ${ }^{5, *(\mathbb{D}}$, \\ Rewaa S. Jalal ${ }^{6}{ }^{\circ}$, Bushra Ahmed Alhammad ${ }^{7}$, Khalid F. Almutairi ${ }^{2}\left(\mathbb{D}\right.$ and Adel M. Al-Saif ${ }^{2}$
}

1 Department of Water Resources and Environmental Management, Faculty of Agricultural Technology, Al Balqa Applied University, Salt 19117, Jordan; Drhibakh@bau.edu.jo

2 Plant Production Department, College of Food and Agriculture Sciences, King Saud University, P.O. Box 2460, Riyadh 11451, Saudi Arabia; mseleiman@ksu.edu.sa (M.F.S.); almutairik@ksu.edu.sa (K.F.A.); adelsaif@ksu.edu.sa (A.M.A.-S.)

3 Department of Crop Sciences, Faculty of Agriculture, Menoufia University, Shibin El-kom 32514, Egypt; mahmoud.seleiman@agr.menofia.edu.eg

4 Department of Animal Sciences, Cornell University, Ithaca, NY 14850, USA; mlb487@cornell.edu

5 Biology Department, College of Sciences, Princess Nourah bint Abdulrahman University, Riyadh 11617, Saudi Arabia

6 Department of Biology, College of Sciences, University of Jeddah, Jeddah 21493, Saudi Arabia; rsjalal@uj.edu.sa

7 Biology Department, College of Science and Humanity Studies, Prince Sattam Bin Abdulaziz University, Al Kharj Box 292, Riyadh 11942, Saudi Arabia; b.alhammad@psau.edu.sa

* Correspondence: Ayshami@pnu.edu.sa

Citation: Alkharabsheh, H.M.; Seleiman, M.F.; Battaglia, M.L.; Shami, A.; Jalal, R.S.; Alhammad, B.A.;

Almutairi, K.F.; Al-Saif, A.M. Biochar and Its Broad Impacts in Soil Quality and Fertility, Nutrient Leaching and Crop Productivity: A Review. Agronomy 2021, 11, 993. https:// doi.org/10.3390/agronomy11050993

Academic Editor: Lukas Trakal

Received: 20 April 2021

Accepted: 10 May 2021

Published: 17 May 2021

Publisher's Note: MDPI stays neutral with regard to jurisdictional claims in published maps and institutional affiliations.

Copyright: (C) 2021 by the authors. Licensee MDPI, Basel, Switzerland. This article is an open access article distributed under the terms and conditions of the Creative Commons Attribution (CC BY) license (https:// creativecommons.org/licenses/by/ $4.0 /)$.

\begin{abstract}
Biochar is gaining significant attention due to its potential for carbon (C) sequestration, improvement of soil health, fertility enhancement, and crop productivity and quality. In this review, we discuss the most common available techniques for biochar production, the main physiochemical properties of biochar, and its effects on soil health, including physical, chemical, and biological parameters of soil quality and fertility, nutrient leaching, salt stress, and crop productivity and quality. In addition, the impacts of biochar addition on salt-affected and heavy metal contaminated soils were also reviewed. An ample body of literature supports the idea that soil amended with biochar has a high potential to increase crop productivity due to the concomitant improvement in soil structure, high nutrient use efficiency (NUE), aeration, porosity, and water-holding capacity (WHC), among other soil amendments. However, the increases in crop productivity in biochar-amended soils are most frequently reported in the coarse-textured and sandy soils compared with the fine-textured and fertile soils. Biochar has a significant effect on soil microbial community composition and abundance. The negative impacts that salt-affected and heavy metal polluted soils have on plant growth and yield and on components of soil quality such as soil aggregation and stability can be ameliorated by the application of biochar. Moreover, most of the positive impacts of biochar application have been observed when biochar was applied with other organic and inorganic amendments and fertilizers. Biochar addition to the soil can decrease the nitrogen $(\mathrm{N})$ leaching and volatilization as well as increase NUE. However, some potential negative effects of biochar on microbial biomass and activity have been reported. There is also evidence that biochar addition can sorb and retain pesticides for long periods of time, which may result in a high weed infestation and control cost.
\end{abstract}

Keywords: biochar; abiotic stress; sustainable agriculture; nitrogen losses; water productivity; soil quality

\section{Introduction}

Biochar, known as charred biomass or black carbon, is an organic material derived from different forms of organic biomass, such as wood, crop residues, animal manure, chicken manure, and municipal sludge, through pyrolysis under a broad temperature range 
(300-1000 ${ }^{\circ} \mathrm{C}$ ) and partial or anaerobic conditions [1,2]. Besides its major component of $\mathrm{C}$, biochar also contains hydrogen $(\mathrm{H})$, oxygen $(\mathrm{O})$, magnesium $(\mathrm{Mg})$, and macronutrients such as $\mathrm{N}$, phosphorus $(\mathrm{P})$ and potassium $(\mathrm{K})$ that can improve crop production for most crops around the world [3-8]. Biochar has gained significant attention over the last two decades due to its potential as a $\mathrm{C}$ sequestration, bioremediation, soil fertility, wastewater, and overall environmental management tool in agriculture [1]. Biochar addition to the soil has shown beneficial results in terms of increasing nutrient retention, providing shelters for microorganisms, improving soil structure, and increasing the absorption of nutrients by plants, which ultimately resulted in increases in plant growth and yield $[9,10]$. Biochar is a recalcitrant $C$ that degrades slowly in the soil and can take thousands of years to be fully degraded $[2,11]$.

When biochar is incorporated in the soil, it changes the physiochemical soil properties such as $\mathrm{C}, \mathrm{pH}$, cation exchange capacity (CEC), porosity, surface area, bulk density, water-holding capacity (WHC), nutrient use efficiency (NUE), available P and total N, among the other soil amendments [2,6,12]. Moreover, it reduces the soil hardening and increases the porosity, which positively impacts the soil microbial community and nutrient cycling $[11,13]$. Biochar can also help in the recuperation of degraded and contaminated soils through the long-term adsorption of heavy metals (HMs) and other soil contaminants $[6,14,15]$. However, the final effect that biochar may have in the mentioned parameters is strongly dependent on the feedstock sources, pyrolysis temperature, particle size of biochar, and soil texture $[6,16]$. This review covers the physiochemical properties of biochar, feedstock source, production technology of biochar, effect of biochar on physiochemical properties of soil, nutrient cycling, soil microbial activity, NUE, water use eficiency (WUE), plant growth, production and quality of crops, and potential risks as well as limitations of biochar application on agricultural lands.

\section{Physical and Chemical Properties of Biochar}

The performance of biochar as a soil amendment depends on the specific physiochemical properties such as surface area, bulk density, pore structure and distribution, particle size, WHC, $\mathrm{CEC}, \mathrm{pH}$, presence and richness of different functional groups, which can vary widely among biochars produced from different feedstock sources $[6,10,17]$. Among others, typical feedstock biomass sources for biochar production are forest and crop residues, manures, algae, and municipal and industrial sewage [8,18]. Generally, biochar derived from animal manures, poultry manures, seaweeds, and crop residues have a greater quantity of nutrients, high $\mathrm{pH}$, and less stable $\mathrm{C}$, compared to biochars produced from woody biomass $[10,18]$. Different physical properties of biochar resulting from different feedstock sources can greatly affect the microbial activity, soil WHC, mineral and nutrient retention, and potential sorption of organic compounds $[6,9,19]$.

\subsection{Surface Area, Porosity, Particle Size, and Pore Distribution}

Surface area, high porosity, pore size and distribution are critical characteristics of biochar, as they influence nutrient retention, biochar adsorption capacity, and soil microbial activity [20]. A large surface area is linked to several other properties of biochar such as CEC and WHC; therefore, this is a prerequisite for a number of biochar applications in modern agriculture [2,6]. During pyrolysis, volatiles compounds are released in the form of gases, which can generate a particularly porous honeycomb structure as well as increase the surface area of biochar. As a result, WHC, nutrient retention and their release linearly increase as the surface area and porosity of biochar increase [10,20]. In return, feedstock sources can affect the surface area of biochar. For example, Weber and Quicker [2] reported that biochar produced from sewage sludge had a surface area of $100 \mathrm{~m}^{2} \mathrm{~g}^{-1}$, while the majority of biomasses possess surface areas ranging from 100 to $800 \mathrm{~m}^{2} \mathrm{~g}^{-1}$. In another study, biochar of maize (Zea mays L.) straw had a higher surface area compared to biochar produced from cottonwood or aspen (Populus species) leaf [21]. Likewise, pore volume, size, and pore distribution differ in biochar depending on the feedstock materials and 
pyrolysis temperature. Macropores ( $>50 \mathrm{~nm}$ pore diameter) and mesopores $(2-50 \mathrm{~nm})$ of biochar are helpful for WHC and can act as habitat for soil microorganisms, while micropores or nanopores $(<0.9 \mathrm{~nm})$ of biochar largely govern the chemical and sorption properties of biochar [22]. Pyrolysis temperature also affects the biochar porosity, which increases with the increases in temperature. Moreover, particle size and shape of biochar can play a key role in physiochemical and hydraulic properties of soil. Soil particles interact more easily with fine and small particles of biochar to form the aggregates [23,24] and fill the spaces between soil particles, with the consequent change in the interpore shape, and water retention and mobility within the soil [25].

\subsection{Hydrophobicity}

Hydrophobicity is a result of the condensation of the aliphatic compounds (tars) on the surface of biochar during pyrolysis. It can influence the water retention and microbial interaction of biochar. Biochars produced at low temperature have high hydrophobicity [26], while biochars produced at high temperatures during pyrolysis have greater surface area and pore volume. The latter can cause a higher capillary force and hydrophilicity than the former [27]. The application of biochars with a high hydrophobicity can interrupt water infiltration, turn hydrophilic soils water repellent, and increase the risk of soil erosion [27].

\subsection{Reactivity of Biochar $(\mathrm{pH})$}

Reactivity of biochar affects the CEC of soil, $\mathrm{pH}$, mineralization, precipitation of minerals, mobility, and plant availability of different nutrients [28,29]. In general, biochars are alkaline in nature, and their alkalinity increases with the rise in temperature during the pyrolysis process [20]. High temperature during pyrolysis removes the carboxyl, formyl, or hydroxyl groups, and increases the concentration of inorganic elements and basic oxides. Thus, it can cause an increase in the $\mathrm{pH}$ of biochar [30]. In addition, the $\mathrm{pH}$ of biochars depends on the feedstock materials. For example, biochar produced from lignin-rich material, for instance, nut and shell biomass, has a $\mathrm{pH}$ around 8 , while biochar derived from manure, waste biomass, and algae typically has the highest $\mathrm{pH}$ levels ( 9.5) [31]. When the alkaline biochar with $\mathrm{pH} 7-9$ is incorporated into the acidic soil $(\mathrm{pH}<7)$, it increases the soil $\mathrm{pH}$ and decreases the mobility of cationic metals such as copper $(\mathrm{Cu})$, zinc $(\mathrm{Zn})$, cadmium $(\mathrm{Cd})$, and mercury $(\mathrm{Hg})$ in the soils because of less competition between metal ions and $\mathrm{H}^{+}$ions for cation exchange sites [28,31].

\subsection{Cation Exchange Capacity (CEC)}

Biochars with high CEC can retain more nutrients, reduce nutrient leaching, and increase the absorption of ammonium $\left(\mathrm{NH}^{4+}\right), \mathrm{K}^{+}$, calcium $\left(\mathrm{Ca}^{2+}\right)$, and magnesium $\left(\mathrm{Mg}^{2+}\right)$ from soils to plant roots by releasing $\mathrm{H}^{+}$to balance the charge in the soil $[7,32,33]$. The CEC of biochars decreases with the increment in the pyrolysis temperature due to the loss of functional negatively charged groups and low pyrolysis temperature $\left(300-450{ }^{\circ} \mathrm{C}\right)$. On the other hand, producing biochar with a high CEC can adsorb $\mathrm{NH}^{4+}$, among others, and decrease $\mathrm{N}$ leaching [7]. The variability in CEC of biochar also depends on feedstock sources and the specific functional groups formed during pyrolysis that can affect the surface properties of the biochar [34]. For example, the CEC of biochar produced from pig manure was lower $\left(32.7 \mathrm{cmol} \mathrm{kg}^{-1}\right)$ compared to chicken manure biochar $\left(81.4 \mathrm{cmol} \mathrm{kg}^{-1}\right)$ pyrolyzed at $500{ }^{\circ} \mathrm{C}[35]$.

\subsection{Surface Functional Groups}

During pyrolysis of biochar, chemical bonds break and new functional groups such as nitro- $\mathrm{NO}_{2}$, methyl- $\mathrm{CH}_{3}$, hydroxyl-OH, and carboxyl- $\left.(\mathrm{C}=\mathrm{O}) \mathrm{OH}\right)$ are formed on the surface of the biochar [2,36]. Due to the existence of these functional groups as electron acceptors or donors, biochar may be acidic, simple, hydrophilic, or hydrophobic. Pyrolysis temperature influences the functional groups, with increasing temperatures resulting in the elimination of acidic groups such as formyl, carboxyl, or hydroxyl and the enrichment 
of the basic cations in the biochar. As a result, this can increase the alkalinity of the biochar [2,37]. The negative functional groups increase the $\mathrm{pH}$ of soil, as they adsorb metal ions from the soil due to the transfer of protons (deprotonation). Some surface biochar functional groups can also retain HMs by adsorption. For example, animal manure-based biochar and sawdust biochar can increase the immobilization of $\mathrm{Cd}$ through high surface complexation with O-containing groups [38].

\section{Biochar Feedstock Sources}

The wide spectrum of biochar feedstocks, which are responsible for the extensive and dissimilar documented properties of biochar around the world, include switchgrass (Panicum virgatum L.), hardwoods, peanut (Arachis hypogaea L.) hulls, maize husk, pecan (Carya illinoinensis) shells, bark, sugarcane (Saccharum officinarum L.), rice (Oryza sativa L.), animal manure, sewage sludge, urban yard wastes, industrial byproducts, and aquaculture waste [1,2]. In general, feedstocks for biochar production have been considered as materials that are abundantly available or waste, or acquired at low price [1,39]. Generally, biomass is divided into woody biomass, which has high bulk density, less void age, high calorific value, low moisture and ash contents, and non-woody biomass, comprised of animal manures, poultry manure, agricultural and crop residues, urban and industrial waste material [40]. Biochars produced from animal manures, crop residues, and seaweeds are richer in nutrients, possess higher $\mathrm{pH}$, and contain less stable carbon than woody biochar [1,31,41,42]. Omotade et al. [43] applied biochar of maize cobs, peanut shells, cow dung, and poultry litter pyrolyzed at $300-600{ }^{\circ} \mathrm{C}$ for $3 \mathrm{~h}$. Results from this research showed that the highest contents of $\mathrm{N}(0.62 \%)$ and $\mathrm{K}\left(16.2 \mathrm{mg} \mathrm{g}^{-1}\right)$ were found in cow dung, $\mathrm{P}$ $\left(66.4 \mathrm{mg} \mathrm{g}^{-1}\right), \mathrm{Mg}(0.28 \%)$, and sulfur $(\mathrm{S} ; 0.28 \%)$ in maize cob, and $\mathrm{Ca}\left(4.21 \mathrm{mg} \mathrm{g}^{-1}\right)$ in peanut shell. Thus, wood-based biochars are suitable when the final objective is carbon storage in soil $[44,45]$, while biochars from animal manures and grasses are used when the objective is to increase the soil N, P, K, Ca, Mg, and S contents [45,46]. According to Ippolito et al. [47], biochars produced from hardwoods supply $0.002,2.2$ and $17 \%$ of the total $\mathrm{N}$, total $\mathrm{P}$, and total $\mathrm{K}$, respectively, while biochars of soft softwoods can supply $27 \%$ total $\mathrm{P}$ and $6 \% \mathrm{~K}[47]$.

Variations in the surface area, pore volume, pore size, $\mathrm{CEC}, \mathrm{pH}$, and other properties of biochar are a consequence of different moisture, cellulose, hemicellulose, and lignin contents present in the original biochar feedstocks [48,49]. Biochar produced from animal litter, poultry manure, and solid waste materials shows a high CEC but lower C content, surface area, and volatile matter compared to biochars derived from wood biomass, agricultural and crop residues [17]. Pariyar et al. [11] produced biochar from different feedstock types, including poultry litter, rice husk, pine (Pinus pinea L.) sawdust, food waste, and paper mill sludge, pyrolyzed at $350-650{ }^{\circ} \mathrm{C}$ for $40 \mathrm{~min}$. They reported that poultry manure biochar had the highest CEC, followed, in decreasing order, by paper mill sludge, pine sawdust, rice husk and food waste. In the same study, paper mill sludge and poultry litter biochars exhibited high $\mathrm{pH}$, while high surface area was found in rice husk and pine sawdust biochars.

\section{Biochar Production Technologies}

Biochar has attracted significant attention in the current organic farming system over the last 20 to 25 years, although its origin is older and associated with the Amazon region, where is commonly known as "terra preta" soil [50]. These dark-colored, highly fertile soils have supported the food and feed requirements of the Amazonians for centuries. At present, several methods of biochar production are available, some of which are described in this section and shown in Figure 1. 


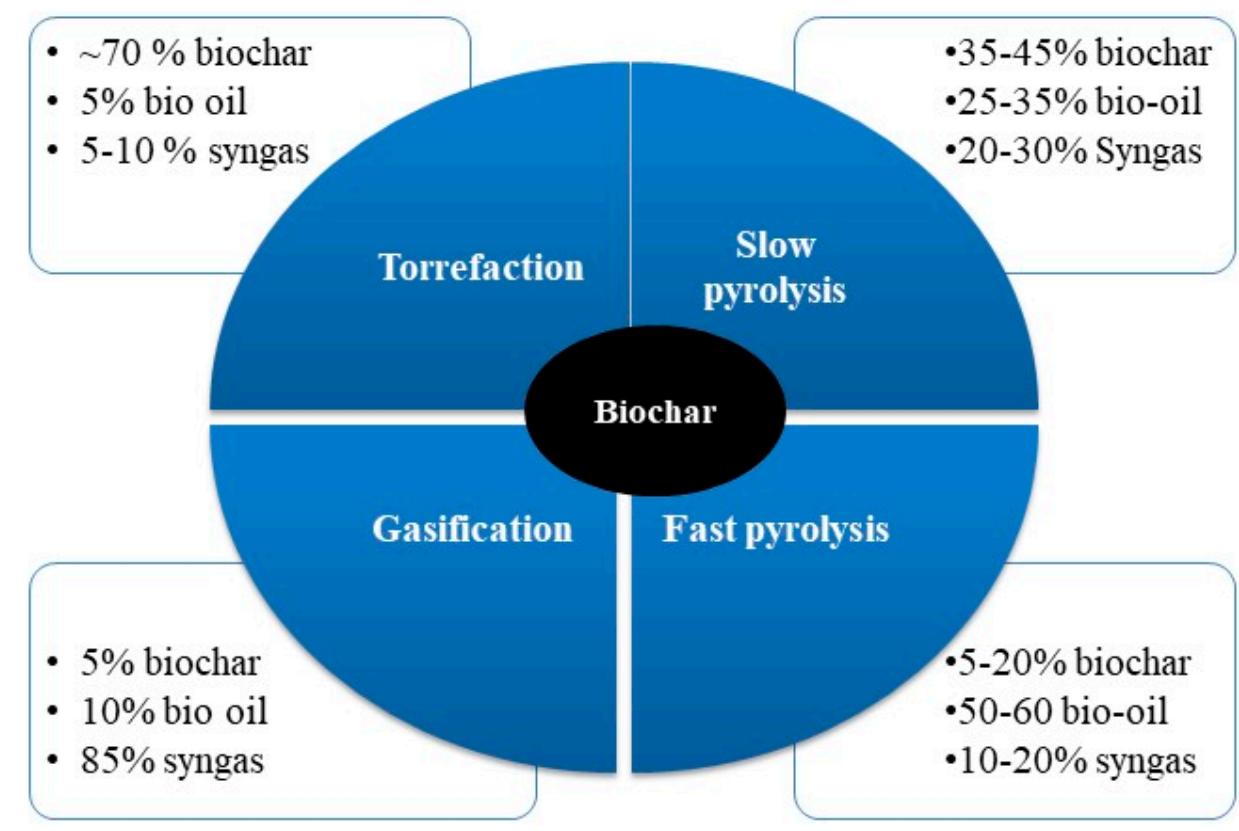

Figure 1. Effect of different pyrolysis methods on biochar yields.

\subsection{Traditional Method}

Archaeological records show that the production and use of biochar started thousands of years ago in the Amazon basin of South America [50]. In ancient times, biochar was produced in two ways: (i) people used to pile the wood in the soil pits, cover these pits with layers of soil, and then burn it slowly with absence of or limited air, or (ii) people used to burn the wood in open air and then immediately cover the half-burned wood with layers of soil $[50,51]$. Over time, these ancient methods of biochar production were replaced with clay burners, firebrick pits, and brick kilns that consist of a pit enclosed by clay, bricks, or metal [50]. These methods contain a fixed-bed reactor system. In earthen or metal kilns, organic biomass is piled up and heated in the absence of air for several hours to days. In all cases, the heating rate is very low in these methods and may not be uniform for all biomass particles because of the slow heat transfer inside the reactors [52]. As a result, biomass particles get more heat the closer they are to the heating unit, and vice versa as they get farther away from it [52]. With the advancement in technology, new methods such as pyrolysis, gasification, and torrefaction, which yield more and higher quality biochar, started to be used, although the principle is the same in all cases [1].

\subsection{Pyrolysis}

The word pyrolysis is the combination of the words "lysis" (breaking down) and "pyro" (heat). In this process, thermal degradation of biomass occurs at temperatures ranging between $350{ }^{\circ} \mathrm{C}$ and $1000{ }^{\circ} \mathrm{C}$ in kilns, retorts, and other specific equipment under partial or total lack of oxygen to produce biochar, bio-oil, and synthetic gas (syngas) (Figure 2) $[49,53]$. The recovery percentage of each product depends on different factors such as feedstock source, pyrolysis temperature, and heating rate. Bio-oil is a dense mixture of cyclic compounds, which requires less reforming and thus is ready for different usages. Syngas is obtained as a byproduct during pyrolysis when plastic is used as a parent material or feedstock $[54,55]$. On the basis of temperature, heating rate, residence time, and operating parameters, pyrolysis is divided into slow and fast pyrolysis $[1,56]$. 


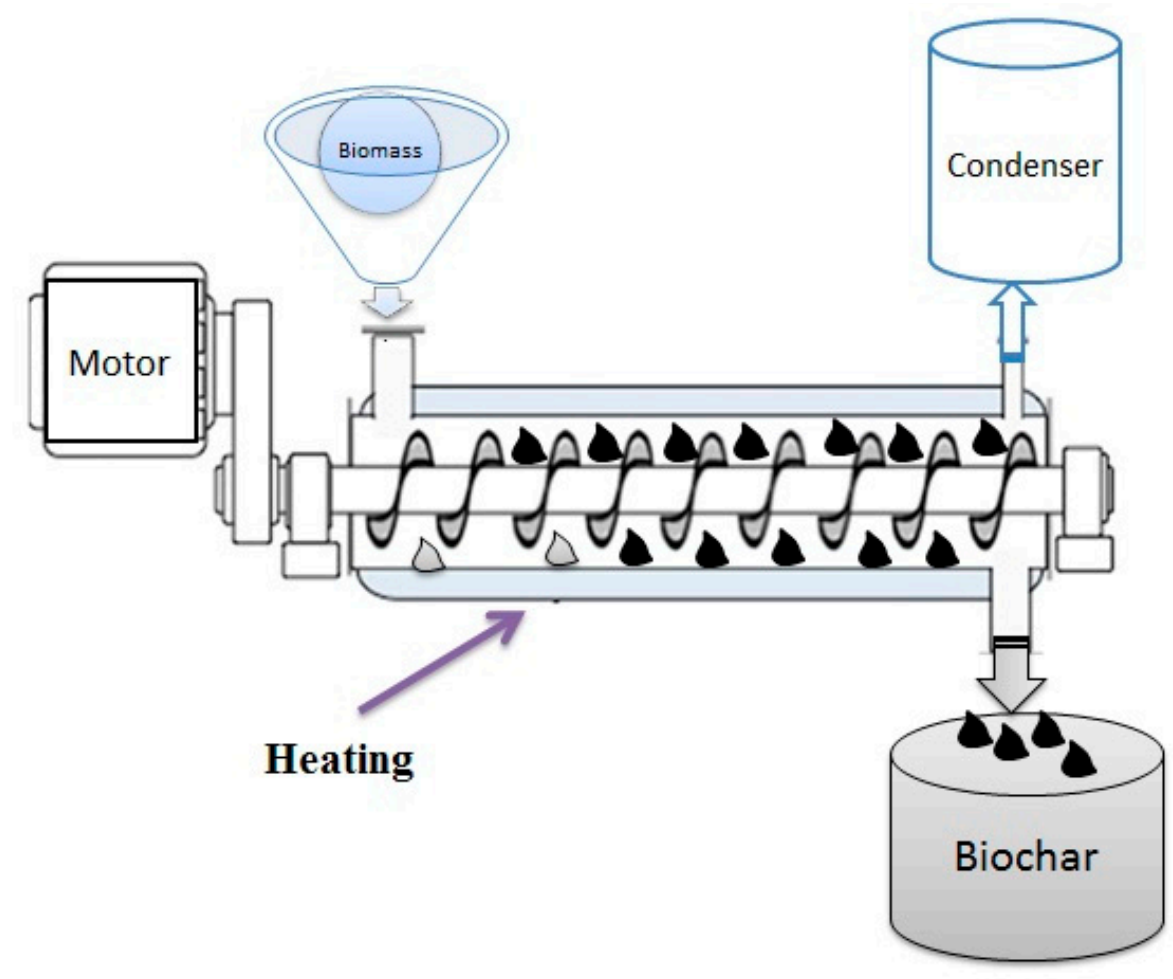

Figure 2. Simple illustration of pyrolysis method.

\subsubsection{Slow Pyrolysis}

As the name indicates, the slow pyrolysis process takes several hours to be completed. In slow pyrolysis, biomass is decomposed at $300-800{ }^{\circ} \mathrm{C}$ and slow heating rate $\left(0{ }^{\circ} \mathrm{C} \mathrm{s}^{-1}\right.$ to up to $10^{\circ} \mathrm{C} \mathrm{s}^{-1}$ ) compared to fast pyrolysis [1]. The process generally occurs at atmospheric pressure with energy provided by an external source. In slow pyrolysis, the major product is biochar $(35-45 \%)$ (Figure 1) followed by bio-oil $(25-35 \%)$ and syngas $(20-30 \%)$ [50,57]. This review describes the slow pyrolysis using an auger reactor, although rotary kilns and other reactors are also used in practice, because of its simplicity in design and operation and its wide use by small and mid-size industries [53,58]. In this method, the feedstock material is continuously supplied to a screw and the biomass moves along the axis, following the auger rotation, to reach the end of the heating zone. Another advantage of this method is that rotational speed of the screw and the residence time of biomass can be easily controlled without halting biochar production [53]. Often, an inert gas is fed to ensure no oxygen entry along with feedstock, and this gas develops a small positive pressure to transport the pyrolysis vapors [59,60]. For small diameter reactors, the biomass carrying tube is heated by a heat unit located outside of the tube, while for larger diameter reactors, a solid heat carrier (hot steel-shot or sand) that interacts with biomass particles is used in the reactor tube [60]. The gases and organic volatiles produced during the pyrolysis process leave the reactor and are collected in a condenser to form the bio-oil, while the biochar is collected in a char pot located at the bottom of the reactor [53].

\subsubsection{Fast Pyrolysis}

Fast pyrolysis is carried out at temperatures between 350 and $1000{ }^{\circ} \mathrm{C}$ in the absence of oxygen, similar to the case for slow pyrolysis, although the heating rate in this case $\left(17^{\circ} \mathrm{C} \mathrm{s}^{-1}\right)$ is much higher compared to slow pyrolysis $[1,56]$. In fast pyrolysis, small particles of feedstock $>2 \mathrm{~mm}$ are used, which rapidly decompose to generate biochar, vapors, and organic volatiles (Figure 3) [61]. In this process, biochar yield is less (20\%), syngas similar $(20 \%)$, and bio-oil production higher $(60 \%)$ compared to that produced with slow pyrolysis (Figure 1) [50]. Higher pyrolysis temperature increases both the surface area and $\mathrm{C}$ content of biochar due to the release of organic volatiles from feedstock particles. For 
example, biochar produced from rapeseed (Brassica napus) stem at $200^{\circ} \mathrm{C}$ showed a specific surface area of $1 \mathrm{~m}^{2} \mathrm{~g}^{-1}$ while the same material pyrolyzed at $700{ }^{\circ} \mathrm{C}$ exhibited surface area of $45 \mathrm{~m}^{2} \mathrm{~g}^{-1}$ [21]. Fast pyrolysis process can be run in different pyrolysis reactors such as auger or screw rotator, rotary cone, fluidized bed, circulating fluidized bed, bubbling fluidized bed, and others [62].

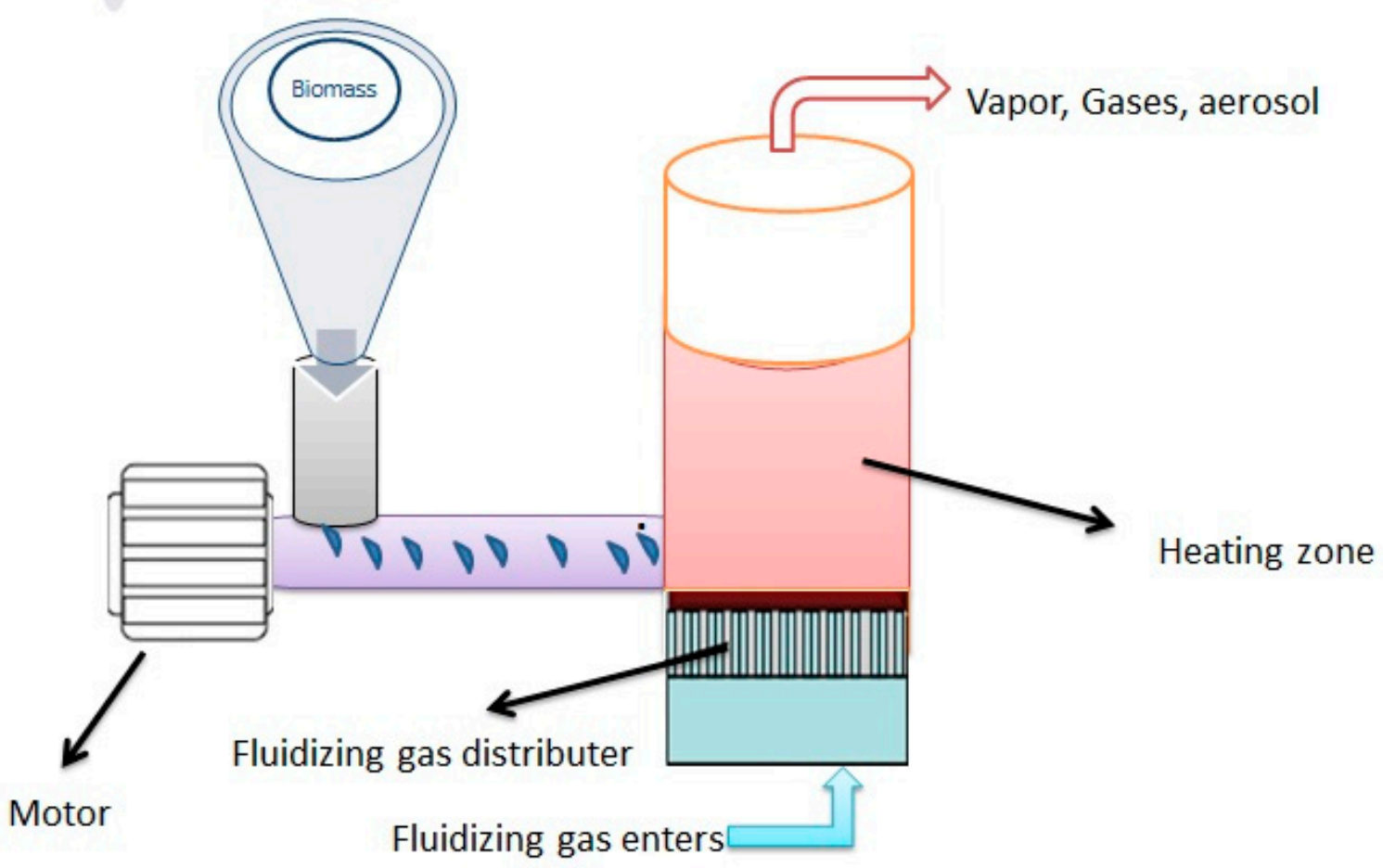

Figure 3. Diagram of a fluidized bed reactor typically used in the production of biochar with the fast pyrolysis process.

Fluidized bed reactors are extensively used in fast pyrolysis because of their high efficiency [59]. The biomass particles enter the fluidized bed from its bottom site and move up through preheated solid inorganic material (sand) by the introduction of pressurized inert gas from the bottom of the reactor [59]. The vigorous motion of hot sand $\left(450-550{ }^{\circ} \mathrm{C}\right)$ and small biomass particles ensures proper mixing and high heat transfer rate to treated biomass [62]. As the pyrolysis process proceeds, the vapors, volatiles, aerosols, and char residues quickly leave the reactor and are collected in separate cyclones [59,62]. Due to its high $\mathrm{C}$ content, biochar produced with the fast pyrolysis process is best suited to be used as a soil amendment and soil $\mathrm{C}$ sequestration tool [62].

\subsection{Gasification}

Gasification is a thermochemical process that is carried out at high temperatures $\left(700-1000{ }^{\circ} \mathrm{C}\right)[1,63]$. As a byproduct, biochar is produced by the gasification process at a rate that is affected by the gasifying agents, oxygen equivalence ratio, gas pressure, and feedstock types used in the process [64]. Generally, biochar yield from the gasification process is very low $\left(200 \mathrm{~g} \mathrm{~kg}^{-1}\right)$ compared to pyrolysis process $\left(200-500 \mathrm{~g} \mathrm{~kg}^{-1}\right)$ [65], while syngas yield is much higher, reaching up to $85 \%$ of the total product outcome (Figure 1). Depending on gasifying agents used, the gasification process is further deemed as $\mathrm{O}_{2}$ gasification (using $\mathrm{O}_{2}$ ), air gasification (using air), $\mathrm{CO}_{2}$ gasification (using $\mathrm{CO}_{2}$ ), or steam gasification (using steam) [63]. The place where the gasification process takes place, commonly known as the gasifier, influences the reactions and the gasification products (Figure 4). Several types of gasifiers, for instance, the fluidized bed, fixed, updraft fixed, and downdraft fixed bed, are currently available [63]. 


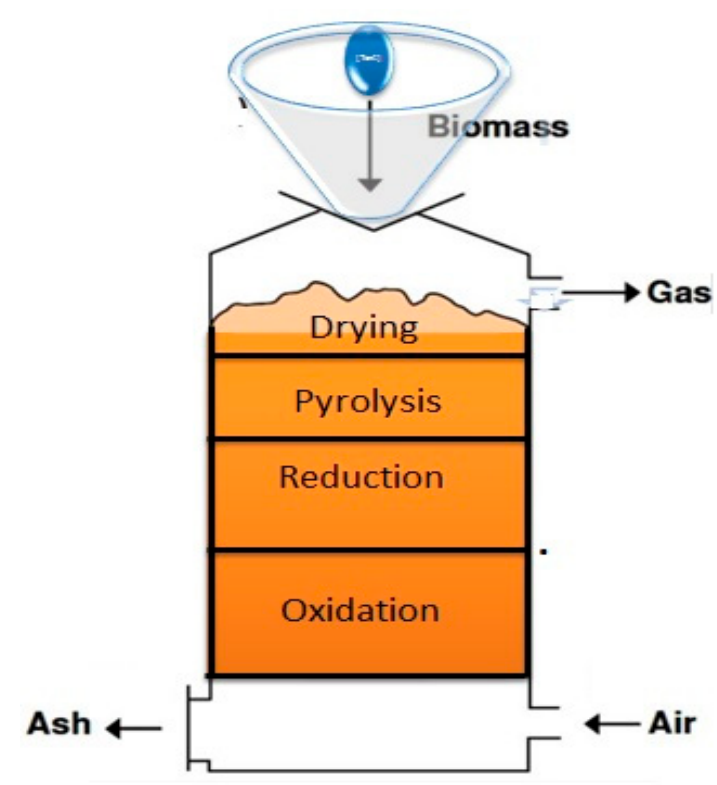

Figure 4. The updraft fixed bed gasifier process, including the spatial location of the oxidation, reduction, pyrolysis, and drying processes occurring in the reactor.

The updraft fixed bed gasifier is usually more popular at small- to medium-scale conditions because of its simplicity, configuration, and low cost [65]. Here, the feedstock material is fed from the top while the air enters from the bottom through a grate $[65,66]$. The combustion process starts at the bottom of the updraft fixed bed gasifier, and there the biochar is formed following a drying and de-volatilization process of the treated material. As a result of this activity, the temperature of the lower part of the gasifier can increase up to $727^{\circ} \mathrm{C}$. The hot gases produced at the bottom portion of the gasifier move upward and mix with the downward feedstock in the reduction portion, reducing the moisture content of this material and decreasing the temperature of the reactor to about $200-300{ }^{\circ} \mathrm{C}$ [66]. Finally, the produced gases leave the top of the reactor whereas biochar and ash are collected in a pit located at the bottom of the reactor. In this process, the collected biochar yield depends on the feedstock, temperature, gasifiers, gasifying agents, and $\mathrm{O}_{2}$ flow rate utilized $[65,66]$. Yao et al. [67] reported that biochar yield was decreased from 0.22 to $0.14 \mathrm{~kg} \mathrm{~kg}^{-1}$ biomass when the $\mathrm{O}_{2}$ flow rate was increased from 0.1 to $0.6 \mathrm{~kg} \mathrm{~h}^{-1}$. Likewise, Muvhiiwa et al. [68] observed that increasing the $\mathrm{O}_{2}$ flow rate from 0.15 to $0.6 \mathrm{~kg} \mathrm{~h}^{-1}$ reduced the biochar $\mathrm{C}$ content from 93 to $86 \%$.

\subsection{Torrefaction}

Torrefaction, also known as mild pyrolysis, is another emerging thermochemical process for biochar production [69]. In a torrefaction process, feedstock is torrefied at $200-300{ }^{\circ} \mathrm{C}$ for a few minutes to hours at low heat rate $\left(<1{ }^{\circ} \mathrm{C} \mathrm{s}^{-1}\right)$ in the absence of oxygen [70,71]. During the initial process, feedstock is heated at a temperature between 160 and $180^{\circ} \mathrm{C}$ to remove the moisture from the feedstock, and then the temperature is increased up to $200{ }^{\circ} \mathrm{C}$. When the temperature is between 250 and $270{ }^{\circ} \mathrm{C}$, a partial decomposition process of biomass starts, resulting in the release of additional moisture, $\mathrm{CO}_{2}$, and acetic acid [71].

The torrefaction process can be performed in various types of reactors. Broadly, there are two main categories of torrefaction reactors: the indirect and the direct heating reactor. Indirect heating reactors are further divided into auger and rotatory reactors. Likewise, direct heating reactors are divided into microwave, moving bed reactors, auger and rotatory reactors, multiple zones and vibrating belt reactors [71,72]. Among these types, auger reactors are the most frequently used because of their simple installation in large industrial-scale structures, less demand of inert gas, and low price. In auger reactors, feedstock is fed to the feeding screw, and then it is transported by a screw conveyor to 
the first reactor where the feedstock is directly heated by the heating material located in the wall, or indirectly by a heating device. Following drying in the first reactor, the feedstock falls by gravity into a second reactor where the torrefaction process is completed. The total length of the overall process, also known as residence feedstock time, mainly depends on the feedstock type used, length of the screw, and the reactor speed. At the end of the torrefaction process, the resulting biochar is removed from the lower portion of the torrefaction reactor, while the gas is collected in a separate condenser (Figure 5) [72]. The biochar yield from torrefaction is much higher than pyrolysis due to the lower temperature utilized in the torrefaction process (Table 1). For example, Liu et al. [73] reported that biomass heated at $290{ }^{\circ} \mathrm{C}$ for 10 and 40 min yielded 80 and $62 \%$ of biochar, respectively.

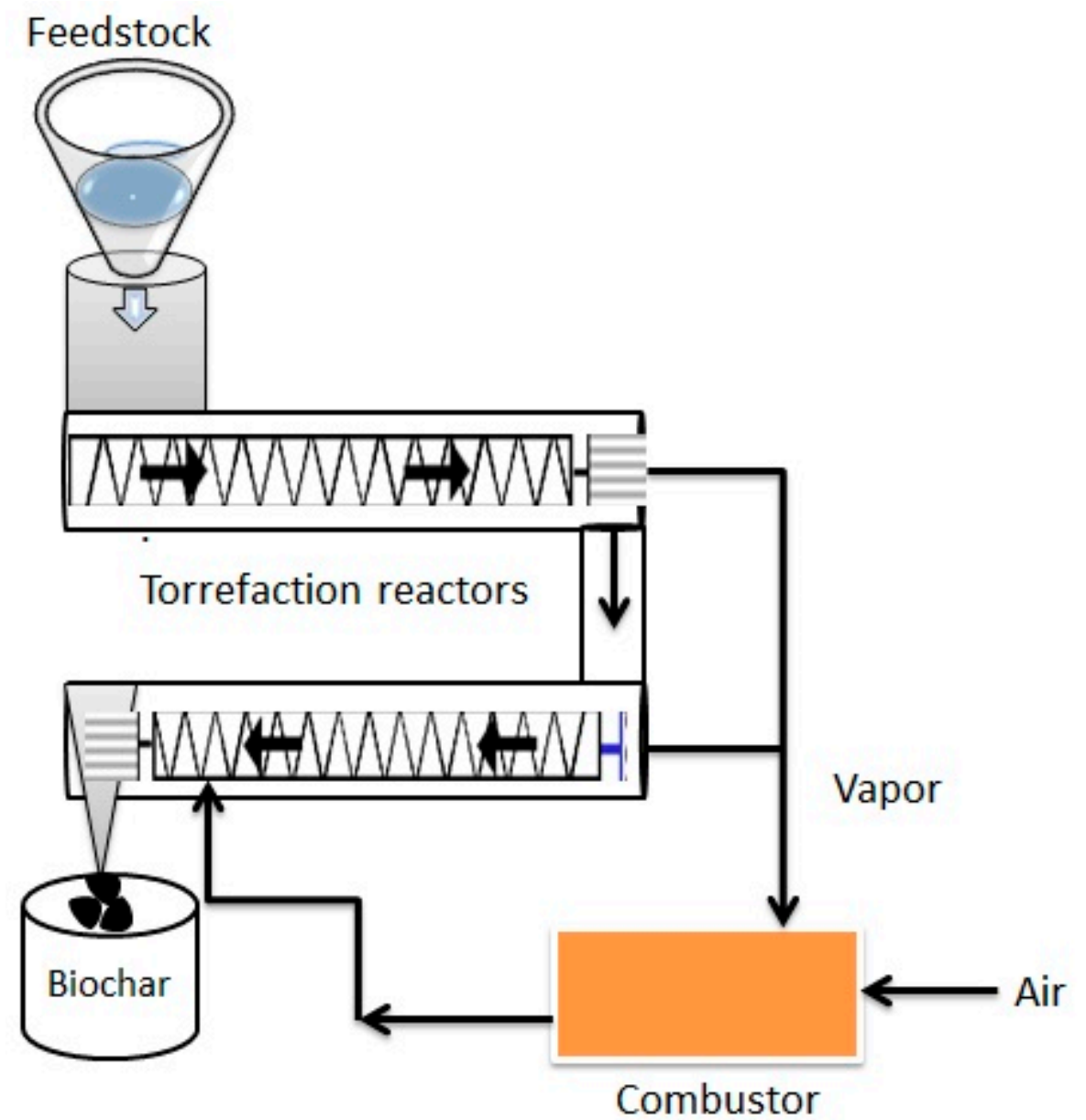

Figure 5. Simple illustration of torrefaction process.

Table 1. Average ranges for the process conditions in biochar production technologies most used at present, including slow and fast pyrolysis, gasification, and torrefaction, and yield of the main products for each technology [1,50,74].

\begin{tabular}{ccccc}
\hline & Slow Pyrolysis & Fast Pyrolysis & Gasification & Torrefaction \\
\hline Temperature $\left({ }^{\circ} \mathrm{C}\right)$ & $300-800$ & $350-1000$ & $700-100$ & $200-300$ \\
Heating rate $\left({ }^{\circ} \mathrm{C} / \mathrm{s}\right)$ & $0.1-10$ & $10-200$ & $5-100$ & $0.2-10$ \\
Feedstock particle size $(\mathrm{mm})$ & $5-50$ & 2 & $>1 \mathrm{~h}$ & 0.2 \\
Solid residence time & Hours to days & $0.5-10 \mathrm{~s}$ & 5 & $60-80$ \\
Biochar yield $(\%)$ & $35-45$ & $5-20$ & 10 & 5 \\
Bio-oil yield $(\%)$ & $25-35$ & $50-60$ & 85 & $5-10$ \\
Syngas yield $(\%)$ & $20-30$ & $10-20$ & & $\mathrm{~h}$ \\
\hline
\end{tabular}




\section{Impact of Biochar on Soil Properties}

Soil physiochemical properties have significant effects on nutrient retention and their uptake, crop growth and productivity, and microbial activities [6,75]. Studies have shown that biochar (Table 2) has the potential to improve the physiochemical and biological properties of soil, creating a suitable environment for plant roots, nutrient uptake, and plant growth [1,23]. Among other characteristics, biochar application affects soil water infiltration, WHC, aggregate stability, soil aeration and porosity, bulk density, soil hardening, $\mathrm{pH}$, CEC, and nutrient cycling $[12,18,76,77]$.

\subsection{Soil Porosity}

Porosity indicates the pore space between soil particles and affects the soil aeration, nutrient retention, and water movement within the soil [23]. Porosity differs among different soil textures, where clayey soils have the highest and sandy soils have the lowest porosity. Biochar can increase the soil porosity by decreasing soil packing and bulk density, and increasing soil aggregation [23]. Zhang et al. [63] concluded that biochar application increased the capillary and the total soil porosity by 23 and $24 \%$, respectively, when compared to the un-amended soil (control). Likewise, Adekiya et al. [77] reported a 65\% increase in soil porosity when biochar was applied compared to the control (untreated soil). Studies showed that biochar did not equally increase the soil porosity even when the same rate was applied, likely a consequence of differences in soil type and soil textural classes in different studies. In general, coarse-textured soils have shown a significant improvement in the porosity after biochar application compared to fine-textured soil [78]. Moreover, the increases in the soil porosity can be an indirect consequence of the decreases in the soil bulk density, as reported by Blanco-Canqui [23], who observed an increases of up to $41 \%$ in the soil porosity following reduction in the soil bulk density.

\subsection{Soil Water Holding Capacity (WHC)}

Soil water retention or WHC indicates the maximum quantity of water that a soil can retain or hold. Several field studies have demonstrated that application of biochar increased soil water retention by positively affecting the soil porosity space between biochar particles and other structural and textural properties of soil $[79,80]$. Besides the porosity between biochar particles, biochar particles also have intrapore space (space inside the particles) that provide additional space for water retention or storage [81]. Soil water infiltration rate and moisture content considerably increased after biochar application at a rate of $30 \mathrm{Mg} \mathrm{ha}^{-1}$ [77]. Kätterer et al. [82] reported that continuous application of biochar for 10 years significantly increased WHC of soil compared with un-amended soil. The rate of applied biochar also affects the soil moisture content. For instance, Ndor et al. [83] applied sawdust and rice husk biochar each at $5-10 \mathrm{Mg} \mathrm{ha}^{-1}$ and recorded $10.8 \%$ increase in soil moisture content compared with no biochar application. Similarly, Are [84] reported a $33 \%$ increase in moisture content after application of poultry litter biochar into a sandy loam soil.

\subsection{Soil Organic Matter and Soil Organic Carbon Content}

Soil organic matter (SOM) is a key parameter that affects soil health, microbial activity, nutrient cycling, and water retention [85]. Many studies have shown that biochar application can increase soil C content, improve WHC, and increase aggregate formation and stability [1]. However, these responses are highly dependent on the feedstock material utilized, the pyrolysis conditions and application rates, and the types of soil where biochar is applied [86]. Following application of biochar derived from umbrella tree (Maesopsis eminii), silvergrass (Miscanthus sacchariflorus), rice straw, and crop residues, El-Naggar et al. [86] observed increases in the OM content of sandy (42-72\%) and loam soils (32-48\%). Adekiya et al. [77] reported that incorporation of $30 \mathrm{Mg} \mathrm{ha}^{-1}$ of hardwood biochar increased the OM by an average 77, 18, and 9\%, compared to un-amended control, 10 , and $20 \mathrm{Mg} \mathrm{ha}^{-1}$ of biochar across two years, respectively. Yang and $\mathrm{Lu}$ [87] also found 
an increase in the SOM content after applying rapeseed stalk and rice straw biochars. Biochar amendment enhances the soil organic carbon (SOC) but, like other physical and chemical parameters of soil quality, increases are highly related to the feedstock type and the temperature used in the pyrolysis process. Biochar produced at low pyrolysis temperature typically has greater labile $C$ content than biochar produced at higher temperature [88]. High C content of biochar indicates that biochar still contains some quantity of original organic biomass residues. Zhang et al. [63] reported that organic $C$ content in soil increased from 3.1 to $4.9 \mathrm{mg} \mathrm{kg}^{-1}$ after incorporation of biochar. Yao et al. [25] reported an enhancement in the SOM and SOC contents after the application of maize stalks biochar at rates of 50,100 and $200 \mathrm{Mg} \mathrm{ha}^{-1}$. According to Jiang et al. [89], biochar addition can reduce the decomposition of native SOC by adsorbing it on its surface. Thus, it can decrease the amount of native SOC that is available to the enzymatic degradation. However, easily decomposable $\mathrm{C}$ can be released from the surface of biochar and stimulate microbial activity [89].

\subsection{Soil Bulk Density}

Soil bulk density is an indicator of soil health, compaction and soil aeration, and influences water infiltration, rooting depth of plants and movement of nutrient [78]. Soils with high bulk density have a lower capacity than soils with high bulk density. This can increase the absorbing of water and can cause a high penetration resistance to plant roots into the soil. In a recent literature review, Omondi et al. [90] concluded that biochar addition decreased soil bulk density between 3 and $31 \%$ in 19 out of 22 soils. Likewise, Adekiya et al. [77] reported that the addition of $30 \mathrm{Mg} \mathrm{ha}^{-1}$ of biochar decreased soil bulk density up to $75 \%$ compared with the no biochar addition.

Soil texture also plays an important role in the resulting bulk density after biochar application. In general, the application of biochar to the soil results in a greater reduction in the bulk density in coarse than in fine-textured soils [78]. In a series of short-term laboratory studies, maximum decreases of up to $31 \%$ in the soil bulk density after application of biochar were noted in sand, followed by coarse (14.2\%), and fine-texture soils (9.2\%) [81]. Similarly, Blanco-Canqui [23] reported a 14.2 and a $9.2 \%$ reduction in the soil bulk density in a coarse and a fine-texture soil, respectively, after biochar application.

It is hypothesized that at least two mechanisms are responsible for the reductions in the soil bulk density after biochar application. Firstly, soil has a higher bulk density $\left(\sim 1.25 \mathrm{~g} \mathrm{~cm}^{-3}\right)$ than biochar $\left(0.6 \mathrm{~g} \mathrm{~cm}^{-3}\right)$. Thus, biochar application can reduce the soil bulk density through a dilution effect. Secondly, biochar can reduce the bulk density of soil in the long term in part due to the complex interactions that it establishes with soil particles, which further improve soil aggregation and porosity [23].

\subsection{Soil $p H$}

Soil $\mathrm{pH}$ affects the mobility and availability of different nutrients and chemical elements in the soil. Generally, application of biochar to soil increases the soil $\mathrm{pH}$, although changes are strongly driven by the soil type, feedstock material, and the liming value of biochar [91,92]. Martinsen et al. [93] applied biochar rates derived from oil palm (Elaeis guineensis) shell, cacao shell (Theobroma cacao L.), and rice husk (Oryza sativa L.) to 31 acidic soils. They observed an increase in soil pH from 4.7 to 5 when cacao shell biochar was applied, which was greater than those obtained from oil palm shell and rice husk. Similarly, El-Naggar et al. [86] reported a sharp increase in $\mathrm{pH}$ of untreated sandy soil after application of biochar made of umbrella tree (Maesopsis eminii) residues, silvergrass, and rice straw, respectively. Chathurika et al. [94] amended soils with 1 and 2\% (w/w) of Acer woodchip biochar ( $\mathrm{pH}$ 9.7). A significant increase in the soil $\mathrm{pH}$ was recorded after 70 days from biochar application compared to non-biochar-amended soils. However, Sandhu et al. [95] reported no increase in $\mathrm{pH}$ in clay soils that received $10 \mathrm{Mg} \mathrm{ha}^{-1}$ of biochar produced from ponderosa pine (Pinus ponderosa) wood residues, maize stover, and switchgrass (Panicum 
virgatum). This could be due to the combined effect of the buffering effect of the clay soil and the low biochar application rate.

\subsection{Cation Exchange Capacity (CEC)}

CEC is one of the important characteristics of soil that influences the soil fertility and the adsorption of mineral nutrients and ions such as sodium $\left(\mathrm{Na}^{+}\right), \mathrm{Ca}^{2+}, \mathrm{Mg}^{2+}$, $\mathrm{K}^{+}$, and $\mathrm{NH}^{4+}$. Although CEC is a natural and inherent characteristic of any soil, it is not easily changed by management. However, many studies have shown that biochar amendment can increase the CEC of soil [86,94,96-98], which could be due to the presence of strong carboxylic and phenolic functional groups with negative charge on the surface of biochar particles [32,92]. Zhang et al. [63] reported a $21 \%$ increase in the soil CEC after biochar application compared to un-amended soil (control). El-Naggar et al. [86] applied biochars produced from rice straw, silvergrass residues, and umbrella tree to sandy soils and reported CEC increases of 906, 180, and 130\%, respectively, compared to un-amended soil. Adekiya et al. [77] also reported an increase in the CEC of soil after application of biochar at $30 \mathrm{Mg} \mathrm{ha}^{-1}$. Ndor et al. [83] observed a 21\% increase in the CEC of soil following application of $5 \mathrm{Mg} \mathrm{ha}^{-1}$ of biochar produced from rice husk and sawdust, and a 44 and $57 \%$ CEC increase when $10 \mathrm{Mg} \mathrm{ha}^{-1}$ of each biochar was applied, respectively, compared to non-biochar application.

Table 2. Application of biochar and soil response.

\begin{tabular}{|c|c|c|c|c|c|}
\hline Soil Type & Plant Type & Biochar Source & Application Rate & Impact on Soil Parameters & Reference \\
\hline Vertisol silt loam & Sorghum & Acacia & $10 \mathrm{Mg} \mathrm{ha}^{-1}$ & $\begin{array}{l}\text { High soil C, exchangeable } \mathrm{K}^{+}, \mathrm{Ca}^{2+} \text { and } \\
\text { CEC }\end{array}$ & [99] \\
\hline Sandy Loam & Wheat and maize & Biochar & $5-20 \mathrm{Mg} \mathrm{ha}^{-1}$ & $\begin{array}{c}\text { Decreased } \mathrm{pH}, \text { bulk density, soluble } \mathrm{Na} \text {, } \\
\text { increased } \mathrm{CEC}, \mathrm{OM} \text {, total } \mathrm{N} \text {, available } \mathrm{P}, \\
\mathrm{K}, \mathrm{Zn}, \mathrm{Cu} \text { and } \mathrm{Fe} \text { in soil }\end{array}$ & [100] \\
\hline Molisols & & $\begin{array}{l}\text { Maize } \\
\text { stover }\end{array}$ & $\begin{array}{l}30 \mathrm{Mg} \mathrm{ha}^{-1} \text { biochar }+ \\
225 \mathrm{~kg} \mathrm{~N} \mathrm{ha}^{-1}\end{array}$ & After 2 years, $\mathrm{CO}_{2}$ fluxes decreased & [101] \\
\hline Aridisol & & Maize cob & $45 \mathrm{Mg} \mathrm{ha}^{-1}$ & $\begin{array}{l}\text { Decreased OM } \\
\text { decomposition }\end{array}$ & [102] \\
\hline Sandy soil & $\begin{array}{l}\text { Tomato (Solanum } \\
\text { lycopersicum L.) }\end{array}$ & Conocarpus & $4-8 \%(w / w)$ & Decreased Na effects & [103] \\
\hline Clayey & Wheat and maize & Rice straw & $\begin{array}{l}2 \mathrm{Mg} \mathrm{ha}^{-1} \text { biochar }+ \\
400 \mathrm{~L} \text { of compost tea } \\
+ \text { magnetic iron ore } \\
150 \mathrm{~kg} \mathrm{ha}^{-1}\end{array}$ & $\begin{array}{l}\text { Increased CEC and } \\
\text { NPK uptake }\end{array}$ & [104] \\
\hline $\begin{array}{l}\text { Tidal } \\
\text { land soil }\end{array}$ & Maize & Rice hull & $1-5 \%(w / w)$ & Increased $\mathrm{C}$ and decreased $\mathrm{Na}$ & [105] \\
\hline Clay loam & Maize & Maize straw & $10-30 \mathrm{Mg} \mathrm{ha}^{-1}$ & $\begin{array}{l}\text { Increased available } \\
\mathrm{P}, \mathrm{K} \text {, total N }\end{array}$ & [106] \\
\hline Sandy loam & Wheat & Mixed hard wood & $5 \%(w / w)$ & $\begin{array}{l}\text { Decreased } \mathrm{Na} \text { while increased } \mathrm{K}^{+} \text {and } \\
\qquad \mathrm{Ca}^{2+}\end{array}$ & [107] \\
\hline Sandy soil & Wheat & Biochar & $\underset{\mathrm{KNO}_{3}}{4 \mathrm{Mg} \mathrm{ha}^{-1}}+5 \mathrm{~g}$ & Increased uptake of $\mathrm{N}, \mathrm{P}$, and $\mathrm{K}$ & [108] \\
\hline Sandy loam & $\begin{array}{l}\text { Potato (Solanum } \\
\text { tuberosum L.) }\end{array}$ & $\begin{array}{l}\text { Mixture of } \\
\text { hardwood }\end{array}$ & $5 \%(w / w)$ & Decreased $\mathrm{Na}^{+} / \mathrm{K}^{+}$ratio & [109] \\
\hline Loamy sand & $\begin{array}{l}\text { Radish (Raphanus } \\
\text { raphanistrum) }\end{array}$ & - & $2.5 \mathrm{Mg} \mathrm{ha}^{-1}$ & Increased $\mathrm{N}$ and $\mathrm{P}$ in soil & [110] \\
\hline Aqui-Entisol & Maize & Wheat straw & $\begin{array}{l}12 \mathrm{Mg} \mathrm{ha}^{-1} \text { biochar }+ \\
\text { poultry manure }\end{array}$ & $\begin{array}{l}\text { Decreased } \mathrm{NaCl} \text { content in leaf, } \\
\text { increased } \mathrm{P} \text { and } \mathrm{K}\end{array}$ & [111] \\
\hline Red Ferrosol & & $\begin{array}{l}\text { willow wood } \\
\text { (Salix spp.) }\end{array}$ & $2.5 \mathrm{Mg} \mathrm{ha}^{-1}$ & Increased soil pH (1.73\%) & [112] \\
\hline Calcareous soil & & Mature switchgrass & $1-10 \%(w / w)$ & Decreased soil pH & [112] \\
\hline Loamy sand & & $40 \mathrm{tha}^{-1}$ & & Increased soil pH 70\% & [113] \\
\hline
\end{tabular}


Table 2. Cont.

\begin{tabular}{|c|c|c|c|c|c|}
\hline Soil Type & Plant Type & Biochar Source & Application Rate & Impact on Soil Parameters & Reference \\
\hline- & - & Rice straw & $3 \mathrm{Mg} \mathrm{ha}^{-1}$ biochar & $\begin{array}{l}\text { Increased capillary porosity }(23 \%) \text { and } \\
\text { total porosity of soil }(24 \%) \text { Increased soil } \\
\text { C from } 3.1 \mathrm{mg} / \mathrm{kg} \text { to } 4.9 \mathrm{mg} / \mathrm{kg}\end{array}$ & {$[63]$} \\
\hline- & - & Hardwood & $30 \mathrm{Mg} \mathrm{ha}^{-1}$ & Soil porosity increased by $65.0 \%$ & {$[77]$} \\
\hline- & - & $\begin{array}{l}\text { Different types of } \\
\text { biochars }\end{array}$ & Various rates & $\begin{array}{c}\text { Increased porosity } 3 \text { to } 31 \% \text { while bulk } \\
\text { density decreased by } 14 \text { to } 64 \% \text {, } \\
\text { Increased soil wet aggregate stability up } \\
\text { to } 226 \%\end{array}$ & {$[23]$} \\
\hline- & - & Acacia spp. & $50+50 \mathrm{Mg} \mathrm{ha}^{-1}$ & Increased WHC of soil and pH & {$[82]$} \\
\hline- & - & $\begin{array}{l}\text { Sawdust and rice } \\
\text { husk-based biochar } \\
\text { each at } 5-10 \mathrm{tha}^{-1}\end{array}$ & 5-10 $\mathrm{Mg} \mathrm{ha}^{-1}$ & $\begin{array}{l}\text { Increased } 10.77 \% \text { soil moisture content, } \\
\quad 36.47 \% \text { increase in porosity }\end{array}$ & {$[83]$} \\
\hline- & - & $\begin{array}{l}\text { Umbrella tree, } \\
\text { silvergrass, rice straw, } \\
\text { and crop residues }\end{array}$ & $30 \mathrm{Mg} \mathrm{ha}^{-1}$ & $\begin{array}{c}\text { Increased OM content of sandy soil } \\
(42-72 \%) \text { and loam soil }(32-48 \%) \\
\text { Increased pH of sandy soil by } \\
46.75-86.26 \% \text {. Increased CEC by } \\
130-906 \% \text {. }\end{array}$ & {$[84]$} \\
\hline- & - & $\begin{array}{l}\text { Rapeseed stalk and } \\
\text { rice straw }\end{array}$ & $1 \%(w / w)$ & Increased $\mathrm{pH}, \mathrm{SOM}, \mathrm{CEC}$ of soil & [87] \\
\hline- & - & Maize stalks biochar & $2-8 \%$ & $\begin{array}{l}\text { Increased total } \mathrm{C}, \mathrm{N} \text {, total } \mathrm{P}, \mathrm{NO}^{3-}, \\
\text { available } \mathrm{K} \text {, but decreased soil bulk } \\
\text { density }\end{array}$ & {$[25]$} \\
\hline- & - & Various feedstocks & Various rates & $\begin{array}{c}\text { Decreased bulk density by } 3-31 \% \text {, soil } \\
\text { porosity by } 8.4 \% \text {, WHC by } 15.1 \% \text {, } \\
\text { aggregate stability by } 8.2 \% \text {, and } \\
\text { saturated hydraulic conductivity by } \\
25.2 \%\end{array}$ & {$[90]$} \\
\hline- & - & $\begin{array}{l}\text { Oil palm, Cacao shell, } \\
\text { and rice husk }\end{array}$ & $30 \mathrm{Mg} \mathrm{ha}^{-1}$ & $\begin{array}{l}\text { Increased soil } \mathrm{pH} \text { from } 4.73 \text { to } 5 \text { in acidic } \\
\text { soil, increased CEC of soil }\end{array}$ & [93] \\
\hline \multirow[t]{2}{*}{-} & - & $\begin{array}{l}\text { Inorganic fertilizers }+ \\
\text { biochar of Acer } \\
\text { woodchip }\end{array}$ & $10-20 \mathrm{~g} \mathrm{~kg}^{-1}$ & Increased soil properties & [94] \\
\hline & & $\begin{array}{l}\text { Ponderosa pine } \\
\text { wood residues, maize } \\
\text { stover, and } \\
\text { switchgrass }\end{array}$ & $10 \mathrm{Mg} \mathrm{ha}^{-1}$ & Increased soil $\mathrm{pH}$ of clay soil & [95] \\
\hline
\end{tabular}

\section{Effect of Biochar on Nutrient Availability and Leaching}

\subsection{Nutrient Availability}

Biochars produced through pyrolysis contain aromatic $\mathrm{C}$ and small quantities of $\mathrm{N}, \mathrm{P}$, $\mathrm{K}, \mathrm{Ca}, \mathrm{Mg}$, S, and other nutrients required for plant growth [41,114]. Biochar ameliorates soil physical and chemical properties such as CEC and surface oxidation of soil, which results in an increase in the plant nutrient availability and their retention in the soil [97]. Incorporation of biochar into soil has shown a positive effect on soil C stability, particularly in soils that have less native OM $[63,89]$.

Usually, solubility of inorganic $\mathrm{P}$ is low because it forms mineral precipitates with $\mathrm{Ca}^{2+}$, aluminum $\left(\mathrm{Al}^{3+}\right)$, and iron $\left(\mathrm{Fe}^{3+}\right)$ or tightly sorbs to the soil mineral phase ( $\mathrm{Al}$ and $\mathrm{Fe}$ oxyhydroxide) $[1,4,91]$. However, previous research has shown that biochar alters soil available $\mathrm{P}$ by (a) acting as a P source itself, (b) altering $\mathrm{P}$ solubility through changes in soil $\mathrm{pH}$, (c) altering adsorption and desorption of specific chelates, and (d) promoting P solubilizing bacteria [16]. Thus, the use of biochar is emerging as a suitable practice to effectively decrease the usage of synthetic fertilizers and increase NUE. Incorporation of maize residue biochar in calcareous soil at $1-2 \%(\mathrm{w} / \mathrm{w})$ increased total $\mathrm{N}$ up to $41 \%$, available $\mathrm{P}$ up to $165 \%$, $\mathrm{K}$ up to $160 \%$, and manganese (Mn), $\mathrm{Fe}, \mathrm{Zn}$, and $\mathrm{Cu}$ up to $21,17,42$, and $10 \%$ compared to the un-amended soil (control), respectively. Similarly, Adekiya et al. [77] 
reported higher concentration of $\mathrm{N}, \mathrm{P}, \mathrm{K}, \mathrm{S}, \mathrm{Ca}$, and $\mathrm{Mg}$ in biochar-amended soils than in the un-amended soil with biochar. These results are in conflict with those reported by Yao et al. [25], who also observed an increase in total soil $\mathrm{N}$ but a decrease in the total $\mathrm{P}$ after addition of maize stalks biochar at a rate between 50 and $200 \mathrm{Mg} \mathrm{ha}^{-1}$. In addition, Mclennon et al. [80] reported that the application of biochar, individually or in combination with $\mathrm{N}$ fertilization, did not enhance nutrient concentration and nutrient removal such as $\mathrm{N}$ and $\mathrm{P}$.

Several studies indicated that nutrient contents in biochar and their release to soil solution depend on the feedstock materials and C:N ratio. For instance, El-Naggar et al. [115] observed that only $4.5 \%$ of the total $\mathrm{N}$ in wood biochar was soil-available after incorporation in the soil. Likewise, Figueredo et al. [116] observed that biochar derived from sewage sludge showed higher $\mathrm{N}$ content $(3.17 \%)$ than sugarcane biochar $(1.4 \%)$ and eucalyptus wastes biochar $(0.4 \%)$. The benefits of biochar amendment are more evident in sandy soils, followed by sandy loam and then fine-textured soils [23]. El-Naggar et al [86] found higher total $\mathrm{N}$ content $(125 \%)$ in sandy soil compared to sandy loam soil (22\%) after addition of rice straw biochar.

\subsection{Nutrient Leaching}

Nutrient leaching is a major problem in agricultural systems. Mobile nutrients move downward below the rooting zone of plants and thus become unavailable for plant uptake [96]. Biochar can significantly reduce the nutrient leaching by increasing nutrient retention, soil C content, WHC of soil, and microbial activity [97,117]. It is a valuable approach to sorb nutrients such as $\mathrm{N}$ and $\mathrm{P}$ for mitigating the contamination of surface water [80]. Rubin et al. [117] observed that biochar application at $10 \%(w / w)$ reduced cumulative leaching of $\mathrm{P}(37.7 \%), \mathrm{NH}^{4+}(50.2 \%)$, and nitrate $\left(\mathrm{NO}^{3-}\right)$. The reduction in $\mathrm{NO}^{3-}$ and $\mathrm{NH}^{4+}$ leaching could be due either to the enhanced adsorption of these ions to the surface of biochar, the increased immobilization by the greater microbial biomass resulting from biochar addition, or both [117]. Similarly, Xu et al. [118] reported that biochar reduced the $\mathrm{NO}^{3-}, \mathrm{NH}^{4+}$, and total $\mathrm{N}$ leaching between 19 and 28\%, 16 and 19\% and 19 and $20 \%$, respectively, when compared to the un-amended soil with biochar (control). Application of biochar to the soil can considerably decrease the $\mathrm{N}$ leaching by increasing soil $\mathrm{N}$ retention, decreasing the ammonia $\left(\mathrm{NH}_{3}\right)$ volatilization, or converting it into $\mathrm{NO}^{3-}$ by nitrification [119].

Properties of biochar such as high surface area, porosity, charge density, and CEC are helpful in increasing the retention of nutrients and other organic molecules. However, the sorption capacity of biochar also depends on the feedstock materials and the pyrolysis temperature. For instance, wood-derived biochars have a higher phosphate adsorption capacity than biochar produced from straw residues [117]. In a review from the literature, Gao et al. [96] enumerated several biochar feedstocks, including peanut hull, switchgrass, bamboo, bagasse, maize stover, stalks, pepperwood, filter cake, pecan shells, acacia whole-tree, mixed wood, and sewage sludge, that were reported as effective at decreasing $\mathrm{NO}^{3}, \mathrm{NH}^{4+}$, phosphate $\left(\mathrm{PO}_{4}{ }^{3-}\right), \mathrm{K}^{+}, \mathrm{Ca}^{2+}, \mathrm{Mg}^{2+}$, and $\mathrm{Zn}$ leaching. Likewise, Muhammad et al. [120] observed that biochar decreased leaching of K (24\%), born (B; 25\%), $\mathrm{Cu}(80 \%)$, Mn (37\%), and Zn (33\%) when compared to non-biochar addition.

\section{Effect of Biochar on Soil Microbial Activity}

Soil microorganisms play an important role in OM decomposition, nutrient recycling, maintenance of soil structure, suppression of pests and diseases, and secretion of plant growth promoters [121]. Application of biochar can affect the soil microbial activity and community structure (Figure 6) [16,91] through its important properties such as pore space, surface area, porosity, minerals, surface volatile organic compounds, functional groups, free radicals, and $\mathrm{pH}[91,122]$. Biochar contains $\mathrm{K}^{+}, \mathrm{Mg}^{+2}, \mathrm{Na}^{+}, \mathrm{N}, \mathrm{P}$, and other nutrients that can have long-term beneficial effects in microbial growth upon release into the soil solution [123]. Moreover, some bacteria and fungi that are smaller than the pore size of 
certain biochars can colonize these pore to have protection from soil predators. Furthermore, soluble substances such as sugars, alcohols, acids, ketones, and water molecules stored in mesopores and micropores of biochar can promote microbial activity and alter microbial abundance and composition in soil [4,124]. For example, biochar application in soils cultivated with pepper resulted in increments in the activity and microbial population of Pseudomonas spp., Filamentous fungi and Bacillus species [96]. Following the application of corn residue biochar at 1 and $2 \%(w / w)$ in a calcareous soil, Karimi et al. [97] observed increases in the soil microbial biomass ranging between 20 and 124\% compared to the control. Yao et al. [25] reported a 6.6 to $31.2 \%$ higher fungal abundance after application of 50,100 , and $200 \mathrm{Mg} \mathrm{ha}^{-1}$ of maize stalk biochar than those obtained from un-amended soil with biochar. Biochar-amended soils showed high root nodulation by rhizobia, presumably due to more favorable conditions associated with efficient N-fixation. Seleiman et al. [125] observed that combined application of rice straw biochar and foliar silicon in sunflower (Helianthus annuus L.) under water deficit conditions increased sunflower yield by about $27 \%$ and mycorrhizal spores between 182 and 277\% when compared to the non-treated soil with biochar. Therefore, biochar application to soil can increase microbial activity and abundance.

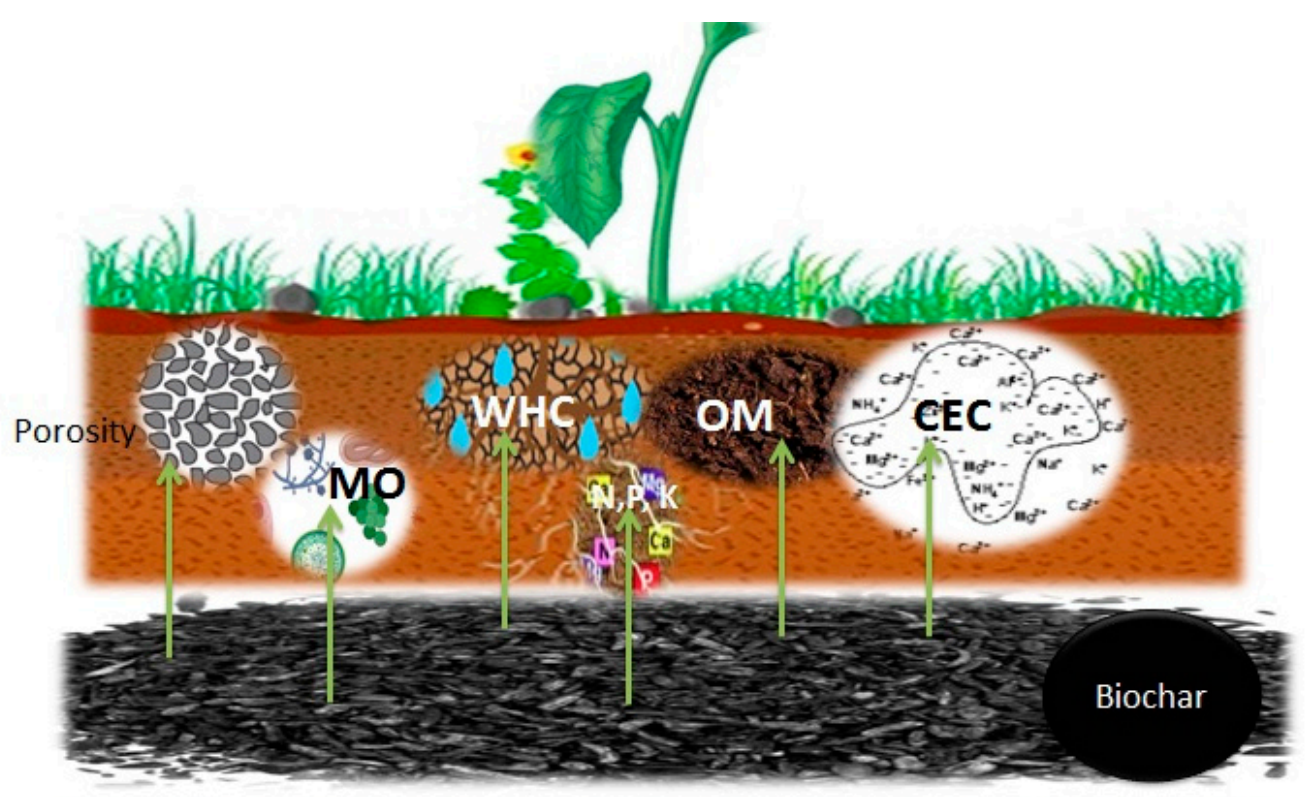

Biochar increases porosity, microorganisms (MO), water holding capacity, organic matter, nutrients and CEC of soil

Figure 6. Beneficial effects of biochar on soil. $\mathrm{OM}=$ organic matter; $\mathrm{WHC}=$ water holding capacity; $\mathrm{CEC}=$ cation exchange capacity.

\section{Impact of Biochar on Salt-Affected Soils}

Soil salinity severely affects crop growth and yield, particularly in arid and semiarid areas of the world [126,127]. Globally, salt-affected areas occupied 1 billion ha, and it is estimated that this area will further expand due to global climate change and poor land and water resources management [128]. There are three types of salt-affected soils, namely, saline, sodic, and saline-sodic soils. Saline soils have a high concentration of soluble salts, while sodic soils contain a high concentration of $\mathrm{Na}^{+}$ions adsorbed at cation exchange sites. Saline-sodic soils possess characteristics of both, with exchangeable sodium $>15 \%$ and electrical conductivity $>0.4 \mathrm{~S} \mathrm{~m}^{-1}$. Salt-affected soils can be cultivated if suitable management practices or measures are adopted [128]. Use of organic amendments in salt-affected soils can produce beneficial effects on plant growth by changing some physiochemical soil properties. Recent studies have shown that addition of biochar amendment in salt-affected soils has gained considerable attention from agricultural scientists $[4,55,128]$. Biochar application to salt-affected soils increased $\mathrm{K}^{+}, \mathrm{Ca}^{+2}, \mathrm{Mg}^{+2}, \mathrm{Zn}^{+2}, \mathrm{Mn}^{+2}$ concentration due to 
a concomitant increase in the CEC, surface area, structure, and porosity of soils, and the stability of organic molecules [129]. In salt-affected soils, high $\mathrm{Na}^{+}$concentration impairs the uptake of $\mathrm{K}^{+}$to plants. However, biochar addition can revert this situation and enhance $\mathrm{K}^{+}$uptake. For example, Lin et al. [130] observed that biochar applied at $16 \mathrm{Mg} \mathrm{ha}^{-1}$ in saline soil substantially increased exchangeable $\mathrm{K}^{+}$by $44 \%$ compared to control. Biochar can improve the NUE of crops as a result of its complex pore structure and large surface area and aeration, which are conducive to enhanced adsorption of $\mathrm{NH}^{4+}$, and a reduction in the inhibition of microbial denitrification [131]. In turn, a reduction in the adsorption of $\mathrm{NH}^{4+}$ can reduce $\mathrm{NH}_{3}$ and nitrous oxide $\left(\mathrm{N}_{2} \mathrm{O}\right)$ losses to the atmosphere $[119,132]$. However, biochar application rates and biochar $\mathrm{pH}$ can also influence the $\mathrm{N}$ volatilization from salt-affected soils. Research has shown that biochar with high $\mathrm{pH}$ (9.6-10.8) increased the $\mathrm{NH}_{3}$ volatilization from salt-affected soil whereas sandy soils amended with low $\mathrm{pH}$ (3.9) biochar reduced the $\mathrm{NH}_{3}$ volatilization $[119,133]$. Thus, biochar with low $\mathrm{pH}$ can effectively reduce $\mathrm{NH}_{3}$ losses form saline-sodic or sodic soils.

Phosphorus availability is higher at soil $\mathrm{pH} 5.5-7$, but $\mathrm{pH}$ of salt-affected soil is $>7$, which decreases $\mathrm{P}$ availability. However, biochar application can increase the $\mathrm{P}$ availability in salt-affected soils because of its inherent fertilizer $\mathrm{P}$ value. Also, it can increase the $\mathrm{P}$ availability by providing favorable conditions for growth of soil bacteria (Flavobacterium, Pseudomonas, and Thiobacillus) that can solubilize unavailable P in soils $[25,128]$.

\section{Impact of Biochar on Soils Contaminated with Heavy Metals (HMs)}

Soil contamination with HMs such as mercury $(\mathrm{Hg})$, lead $(\mathrm{Pb})$, cadmium $(\mathrm{Cd})$, arsenic (As), titanium (Ti) and lithium (Li) is a major global concern. Heavy metals can easily enter and accumulate in the food chain because of their high mobility and bioavailability, causing neurological and immune disorders across different trophic levels. Studies have shown that use of organic materials that have high $\mathrm{pH}, \mathrm{CEC}$, surface area, and porosity such as biochar can ameliorate contaminated soil due to their efficiency at adsorbing HMs from soils (Table 3), [20,115,134]. Field and greenhouse studies have shown that application of biochar increased plant growth and reduced the uptake of HMs [6,74,135,136].

The ionic forms of metals dissolved in soil solution are bioavailable to the plants. Biochar adsorbs the metal ions from contaminated soils due to its stronger sorption sites and high affinity to metal ions [4,137]. Along with the process, both acidic functional groups (carboxylic, hydroxyl, lactonic, and carbonyl) and basic functional groups (pyrone and ketone) play a significant role in the complexation (binding) of HMs onto the surface of biochar and its inner pores [138]. For instance, $\mathrm{HMs}$ such as $\mathrm{Cu}, \mathrm{Zn}, \mathrm{Cr}$, and $\mathrm{Pb}$ may react with carbonate, phosphate, and oxide fractions of the biochar and precipitate on the surface of biochar as insoluble carbonate and phosphate salts $[139,140]$. Exchange of ionic species from the soil matrix to the surface of biochar can also immobilize the target metal species in the soil [139-141]. Penido et al. [142] reported that sewage sludge-derived biochar and wood biochar reduced the bioavailability of $\mathrm{Cd}$ and $\mathrm{Pb}$. Similarly, Meier et al. [143] applied $5 \%$ biochar derived from poultry manure to a soil with a high level of $\mathrm{Cu}$ and observed that biochar reduced the $\mathrm{Cu}$ uptake from stems and leaves of evening primrose (Oenothera picensis) from $66.9 \mathrm{mg} \mathrm{kg}^{-1}$ to $36.6 \mathrm{mg} \mathrm{kg}^{-1}$. Similarly, [144] application of soybean (Glycine $\max$ L.) biochar at $3 \%(w / w)$ rate to an As-contaminated soil decreased As bioaccumulation in the rice plants by $88 \%$. 
Table 3. Reduced uptake of different chemicals after biochar application into soil.

\begin{tabular}{cccc}
\hline Biochar Type & Pollutant & Plant Type & Reference \\
\hline Chicken manure & $\mathrm{Cd}$ & Maize & {$[145]$} \\
Rice straw & $\mathrm{Cd}$ & Rice & {$[146]$} \\
Holm oak & $\mathrm{Cu}$ & White lupin (Lupinus albus L.) & {$[147]$} \\
Holm oak & $\mathrm{Cu}$ & Spinach (Spinacia oleracea) & {$[148]$} \\
Sugar cane bagasse & $\mathrm{Cr}$ & Mash bean (Vigan mungo L.) & {$[149]$} \\
Cotton sticks & $\mathrm{Ni}$ & Spinach & {$[150]$} \\
Cotton sticks & $\mathrm{Ni}$ & Rice & {$[151]$} \\
Pine wood & $\mathrm{Pb}$ & Salix (Salix alba) & {$[152]$} \\
Pinewood & $\mathrm{Pb}$ & Maize & {$[153]$} \\
Rice straw & Methyl mercury & Rice & {$[153]$} \\
Sewage sludge & $\mathrm{Cd}$ and Pb & Soil remediation & {$[142]$} \\
Soybean residues & $\mathrm{Cd}$ & Rice & {$[144]$} \\
Poultry manure & $\mathrm{Cu}$ & Primrose (Oenothera picensis) & {$[143]$} \\
Soybean residues & $\mathrm{As}$ & Rice & {$[144]$} \\
\hline
\end{tabular}

\section{Biochar Application in Combination with Organic and Inorganic Amendments}

Studies have shown that biochar can be applied effectively with organic or inorganic fertilizers, compost, vermicompost, animal manures, and poultry manure to improve soil structure, fertility, NUE, and crop yield [112,154]. Doan et al. [155] applied biochar with vermicompost to maize and observed significant increase in crop growth and yield compared to untreated plots with biochar (control). Addition of willow (Salix alba L.)derived biochar with compost along with synthetic fertilizer significantly enhanced the maize growth in Ferralsol soil [112]. According to Joseph et al. [156], combined application of biochar with manures, composts, or other organic material can improve NUE as a result of slower leaching rates. Zhang et al. [157] mixed organic fertilizer with biochar (1\%) and observed an increase in root and shoot growth of cotton due to improved physiological activity of roots. Similarly, Omara et al. [158] applied N (50-150 kg ha-1) and biochar (5-15 Mg ha ${ }^{-1}$ ) together to maize grown on a sandy soil. Results showed that biochar along with $\mathrm{N}$ increased NUE and maize grain yield. Mixing poultry litter biochar with fertilizers and manure significantly increased growth and fruit yield of cucumber (Cucumis sativa L.) by improving soil fertility and WHC in a sandy soil [159]. Adekiya et al. [77] applied biochar $\left(25-50 \mathrm{Mg} \mathrm{ha}{ }^{-1}\right)$ alone and also in a mix with poultry manure $\left(2.5-5.0 \mathrm{Mg} \mathrm{ha}^{-1}\right)$ in radish (Raphanus raphanistrum). At the end of the first year, authors reported an increase in radish yield for the biochar + poultry manure combined, but not for the biochar alone treatments when compared with the un-amended soil (control). Ibrahim et al. [160] reported higher $\mathrm{N}$ uptake by plants following application of a biochar-N fertilizer compared to either biochar or $\mathrm{N}$ fertilizer alone.

Seleiman et al. [125] applied rice straw biochar $\left(10 \mathrm{Mg} \mathrm{ha}^{-1}\right)$ to sunflower grown under water in three water deficit stress treatments (i.e., $50 \%$, no deficit; $70 \%$, moderate deficit; $90 \%$, severe deficit) [125]. After 30 and $55 \mathrm{~d}$ from germination, $\mathrm{Si}\left(150 \mathrm{~g} \mathrm{ha}^{-1}\right)$ was exogenously applied [124]. Results showed that severe water stress reduced oil and oleic acid contents by 18 and $25.8 \%$ compared to no water stress deficit [125]. When biochar and silicon combined treatment was applied, on the other hand, oil and oleic acid contents increased by 10.2 and $12.2 \%$, respectively [125]. Similarly, seed yield under moderate and severe water deficit increased by about $27 \%$ in both cases when the biochar $+\mathrm{Si}$ treatment was applied, compared with similar water deficit treatments without any amendment [125]. Therefore, for soil fertility and NUE especially, the addition of biochar with either organic or inorganic soil amendment is an appropriate practice.

\section{Biochar for Improving Water Use Efficiency (WUE)}

Water scarcity is predicted to worsen as increasing global warming has altered, and will continue to alter, the hydro-climatic system and created an imbalance in water supply and demand in the world [161]. Soil amendments such as biochar can enhance WUE 
in agricultural system under increasing water-limited conditions [80,125,162]. Pot and field experiments have shown that biochar retains soil water, increases WHC of soil, improves water availability to plants, enhances nutrient uptake, and supports root growth in the soil [112,163]. Fischer et al. [162] observed that biochar increased WUE and crop yields $(75 \%)$ compared to the un-amended soil with biochar (control). Biochar application at 25 and $50 \mathrm{Mg} \mathrm{ha}^{-1}$ on tomatoes grown under water deficit conditions significantly increased WUE compared to no biochar application [164]. Contrasting results were reported by Aller et al. [165], who observed that biochar application decreased WUE in maize grown in clay loam soil but enhanced it in sandy loam soil.

Studies have shown that feedstock materials also affect the WUE of biochar. For instance, the biochar of wood chips reduced plant WUE, while maize straw biochar increased it [144,166]. Faloye et al. [167] applied biochar at $20 \mathrm{Mg} \mathrm{ha}^{-1}$ and observed a substantial improvement in the soil hydro-physical properties and the WUE of maize plants. Likewise, Bitarafan et al. [168] observed an increase in WUE ranging between 10.1 and 17.3\% following biochar application in fenugreek (Trigonella foenum-graecum L.).

\section{Impact of Biochar on Nitrogen Use Efficiency (NUE)}

As an essential component of various proteins, vitamins, amino acids, alkaloids, plant hormones, chlorophyll, ATP (adenosine triphosphate), and DNA, N is required in larger quantities than any other plant nutrient [131]. However; a large portion of the applied $\mathrm{N}$ is lost from agricultural soils due various factors, thereby decreasing both the crop yields and NUE. Nitrogen use efficiency can be enhanced either by increasing plant uptake of applied $\mathrm{N}$ and its translocation to economic parts of plants, by decreasing $\mathrm{N}$ losses from soil system, or both $[80,169]$. Research has shown that application of biochar with $\mathrm{N}$ fertilizers enhanced the fertilizer NUE and increased crop yields, while reducing $\mathrm{N}$ losses [81,170]. Again, beneficial biochar properties in terms of high surface area, porosity, CEC, and abundance of acidic and basic functional groups play key roles in the reduction of $\mathrm{N}$ losses from soils [171].

A recent meta-analysis from 88 peer-reviewed publications published between the beginning of 2010 and mid-2016 revealed that biochar application reduced the $\mathrm{N}_{2} \mathrm{O}$ emissions from soil between 38 and 49\% [172]. Furthermore, the interaction between soil and biochar can affect the $\mathrm{N}$ transformations in the soil profile by changing its CEC, porosity, aeration, $\mathrm{pH}$, and microbial activity [173]. Abbruzzini et al. [174] reported that biochar applied at $0.4-1.9 \%(w / w)$ with $\mathrm{N}$ fertilizer reduced $\mathrm{N}_{2} \mathrm{O}$ emissions up to $71 \%$ compared to soil where $\mathrm{N}$ was applied without biochar. Moreover, biochar enhanced the available $\mathrm{P}$ by $30 \%$ and increased wheat grain yield by $27 \%$ and shoot biomass by $16 \%$ compared to un-amended soil with biochar. Additionally, the concentration of ${ }^{15} \mathrm{~N}$ in grain was $28 \%$ higher in the biochar compared to the non-biochar treatment. Similarly, Sun et al. [175] observed that application of biochar at rates between 5 and $20 \mathrm{Mg} \mathrm{ha}^{-1}$ increased wheat NUE between 5.2 and $37.9 \%$ and grain yield between 2.9 and 19.4\%. However, biochar rates $>30 \mathrm{Mg} \mathrm{ha}^{-1}$ had a negative impact on NUE and grain yield.

\section{Impact of Biochar on Plant Growth and Physiological Traits}

Plant growth depends on adequate concentration of nutrients available in the soil solution, which can easily be taken up by plants. Deficiency of nutrients can decrease the plant growth and yield. Studies have suggested that biochar can increase the availability of $\mathrm{C}, \mathrm{N}, \mathrm{Ca}, \mathrm{Mg}, \mathrm{K}$, and $\mathrm{P}$ to plants because biochar itself is a source of nutrients $[123,176]$. In addition, it can absorb nutrients and then release them in a slow manner, thereby improving nutrient use efficiency. Many studies have shown that biochar amendments significantly increased the growth and biomass in various plant species [125,159]. Incorporation of poultry litter biochar along with manure and fertilizers significantly enhanced biomass and fruit yield of cucumber (Cucumis sativa L.) by increasing soil WHC and nutrient concentration [159]. Yield of field mustard (Brassica rapa L.) was increased by $49 \%$ after the application of biochar compared to untreated soil with biochar [177]. Similarly, Rafique et al. [178] 
observed that soil amended with biochar increased the fresh and dry weight of maize by $50-55 \%$. Sunflower growth and oil yield were increased under moderate and severe water deficit conditions after combined application of rice straw biochar and foliar spray of silicon [125]. Agegnehu et al. [112] and Omara et al. [158] reported an increase in maize growth and yield after the biochar incorporation. Similarly, Zhang et al. [157] observed higher physiological activities of cotton root in biochar-amended soil than those obtained from untreated soil with biochar.

Application of biochar increased stomatal conductance of maize, which resulted in higher photosynthesis rates and increased production of total soluble sugar in soybean plants as compared with un-amended soil control [179]. Higher chlorophyll and N content were measured in wheat plants after biochar application compared to the un-amended soil [107]. Qian et al. [179] observed a significant increase in the chlorophyll (41\%) of soybean plants when grown on a biochar-amended soil compared to the un-amended one. Likewise, Younis et al. [150] reported that plantation of spinach (Spinacia oleracea) on a soil that received biochar and was subjected to moisture stress showed increases in chlorophyll a $(29 \%)$ and b (52\%), total chlorophyll (33\%), and carotenoid (5\%). Similarly, biochar application in rice augmented the plant photosynthetic rate as a result of the increase in the chlorophyll content and plant gas exchange [180]. In another study, plants grown on a biochar-amended soil showed a high concentration of nutrient in leaves, increased protein content (44\%), and lower production of reactive oxygen species under Cd stress [181]. In other studies, biochar application increased the starch and ascorbic acid content [151], and the starch and soluble sugars [179].

\section{Impact of Biochar on Crop Production and Quality}

Raboin et al. [182] observed a maize yield increase ranging from 46 to $58 \%$ after applying biochar at $50 \mathrm{Mg} \mathrm{ha}^{-1}$ along with animal manure in acidic soil. Figure 7 shows soil fertility management and crop yield improvement through biochar application. The increment in the yield was due to the liming effect of biochar, which increased the nutrient availability and improved the CEC of soil. Similarly, Agegnehu et al. [183] found 22 and $24 \%$ increase in seed and pod yields of peanut (Arachis hypogaea L.) grown on wood biocharamended soil at a rate of $25 \mathrm{Mg} \mathrm{ha}^{-1}$ compared to soil fertilized with inorganic fertilizers. Wood biochar improved the WHC of soil, reduced N and P leaching. Also, biochar derived from peanut shell increased the nutrient peanut kernel quality [184]. Palansooriya [33] recorded a higher sweet potato (Ipomoea batatas) yield after biochar application than unamended soil.

Conversely, Gholizadeh et al. [52] observed no difference in maize yield after biochar application compared with control. Also, Mclennon et al. [80] reported that the application of biochar individually or in combination with $\mathrm{N}$ fertilization did not affect the biomass production of Schedonorus arundinacea and Poa pratensis L. These contradictory results likely occurred because of variations in the physiochemical properties of biochar. For example, biochar pyrolyzed at high temperature $\left(\geq 600{ }^{\circ} \mathrm{C}\right)$ can adsorb plant nutrients, thereby decreasing plant uptake. Agegnehu [185] recorded $98-150 \%$ increased maize yield, likely explained by the parallel increase in the plant WUE between 91 and $139 \%$ as a result of manure biochar application. Table 4 presents the effects of biochar as soil amendment on growth and yield traits of different crops. 


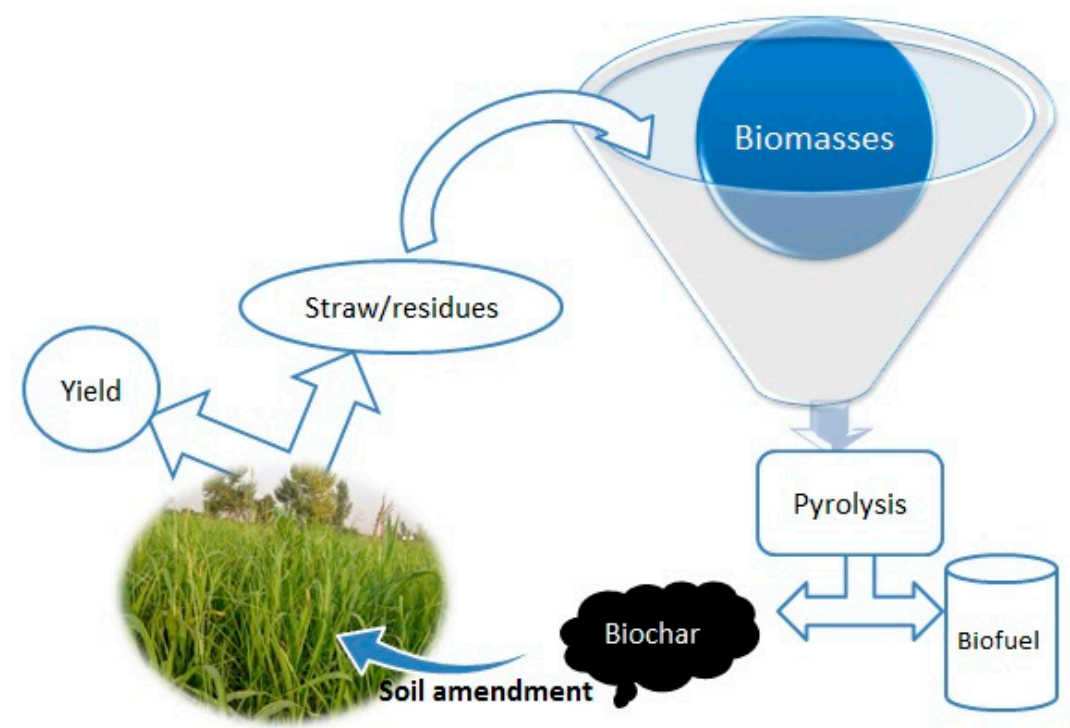

Figure 7. Soil fertility management and crop yield improvement through application of biochar.

Table 4. Effect of biochar on plant growth and yield.

\begin{tabular}{|c|c|c|c|c|c|}
\hline Biochar Source & Application Rate & Soil Type & Plant Type & Crop Responses & Reference \\
\hline $\begin{array}{l}\text { Conocarpus } \\
\text { biochar }\end{array}$ & $4-8.0 \%(w / w)$ & Sandy soil & Tomato & $\begin{array}{l}\text { Increased vegetative growth and } \\
\text { yield increased } 14.0-43.3 \%\end{array}$ & [103] \\
\hline Biochar & $\begin{array}{c}4 \mathrm{Mg} \mathrm{ha}^{-1}+\mathrm{KNO}_{3}(5 \\
\left.\mathrm{g} \mathrm{L}^{-1}\right)\end{array}$ & Sandy soil & Wheat & $\begin{array}{c}\text { Increased height, leaf area, grain } \\
\text { weight and yield by increasing } \\
\text { uptake of N, } \\
\text { P, and K }\end{array}$ & [108] \\
\hline Biochar & $5-20 \mathrm{Mg} \mathrm{ha}^{-1}$ & Sandy Loam & Wheat and maize & Increased yield & [100] \\
\hline Mixed hardwood & $5 \%(w / w)$ & Sandy loam & Wheat & Increased growth and final yield & [107] \\
\hline $\begin{array}{l}\text { Mixture of } \\
\text { hardwoods }\end{array}$ & $5 \%(w / w)$ & Sandy loam & $\begin{array}{l}\text { Potato (Solanum } \\
\text { tuberosum L.) }\end{array}$ & Increased growth and tuber yield & [107] \\
\hline Maize straw & $10-30 \mathrm{Mg} \mathrm{ha}^{-1}$ & Clay loam & Maize & Increased growth and yield & [106] \\
\hline Wheat straw & 0,20 , and $40 \mathrm{Mg} \mathrm{ha}^{-1}$ & $\begin{array}{l}\text { Calcareous } \\
\text { inceptisol }\end{array}$ & Maize & $\begin{array}{l}\text { Significantly increased maize } \\
\text { yield in both years Addition of } \\
\text { nutrients and soil structure and } \\
\text { moisture improvement }\end{array}$ & [186] \\
\hline- & $2.5 \mathrm{Mg} \mathrm{ha}^{-1}$ & Loamy sand & Radish & $\begin{array}{l}\text { Increased root growth, root } \\
\text { diameter, and yield. }\end{array}$ & [110] \\
\hline Wheat straw & $\begin{array}{l}\text { Biochar } 12 \mathrm{Mg} \mathrm{ha}^{-1}+ \\
\text { poultry } \\
\text { manure }\end{array}$ & Aqui-Entisol & Maize & Increased grain yield & [111] \\
\hline $\begin{array}{l}\text { Rice hull-derived } \\
\text { biochar }\end{array}$ & $1-5 \%(w / w)$ & $\begin{array}{l}\text { Reclaimed tidal } \\
\text { land soil }\end{array}$ & Maize & Increased maize yield & [105] \\
\hline Crushed Acacia & 0 and $10 \mathrm{Mg} \mathrm{ha}^{-1}$ & Vertisol & $\begin{array}{l}\text { Sorghum (Sorghum } \\
\text { bicolor L.) }\end{array}$ & No effect on yield & [99] \\
\hline $\begin{array}{l}\text { Biochar + animal } \\
\text { manure }\end{array}$ & $50 \mathrm{Mg} \mathrm{ha}^{-1}$ & acidic soil & & Maize yield increased by $46-58 \%$ & [182] \\
\hline willow wood biochar. & & & Peanut & $\begin{array}{l}\text { Peanut pod yield increased by } \\
\qquad 22-24 \%\end{array}$ & [183] \\
\hline Biochar & & & Sweet potato & Yield increased & [33] \\
\hline Biochar & & & Maize & $\begin{array}{l}\text { Increased yield of maize by } \\
98-150 \% \text { compared to control }\end{array}$ & [185] \\
\hline
\end{tabular}




\section{Limitation of Biochar Application on Soil and Potential Risks}

Use of biochar as an agricultural amendment in agricultural systems has gained notoriety over the last 20 years because of its benefits, including $\mathrm{C}$ sequestration, restoring degraded soils, increasing crop productivity, and decreasing ground and water pollution, among other soil amendments. At present, however, there are still some limitations to the extensive use of biochar applications in modern agriculture. For instance, the application of high doses of biochar, as those typically required to have a positive effect on crop productivity and soil health, has inhibitory effects on soil aging. Consequently, intermittent and split applications of biochar over time would be required in the long-term scenarios of biochar application for better value as a soil amendment and more efficient nutrient cycling in soil [18].

According to Anyanwu et al. [187], aged biochar in the soil has harmful effects on the growth of earthworms. Further, aged biochar has shown a reduction in the roots and shoots biomass of rice and tomato plants. Moreover, evidence demonstrated that the application of biochar can decrease the soil thermal conductivity and diffusivity; therefore, it can negatively influence the soil biochemical processes [145]. In other cases, soils amended with biochar showed less availability of Fe and $\mathrm{P}$ due to the precipitation/sorption of these nutrients $[105,156]$. Moreover, the high sorption capacity of most biochar types determines that the biochar can sorb pesticides and herbicides, which can decrease their efficacy as amendments and increase the problems of high resistance in weeds or pathogens against particular herbicides or pesticides [114]. In addition, biochar application may exacerbate the weed infestation under certain conditions. For example, biochar application at $15 \mathrm{Mg} \mathrm{ha}^{-1}$ increased weed growth by $200 \%$ in an investigation of the lentil. Thus, such a result will not only decrease the crop yield, but will also increase the cost for weed control [188].

The available literature indicates that the potential beneficial effects of biochar are soil type-dependent and do not apply to all types of soils [189]. Moreover, as different biochars have already been derived from hundreds of different organic materials, the nutrient composition of biochars can differ widely, and there is not a specific application rate can be stated.

Studies have shown that some biochars can encourage pollutants such as polycyclic aromatic hydrocarbon, dioxins, xylenols, acrolein, formaldehyde, cresols, and other toxic carbonyls, which can affect the bacterial and fungal abundances in the soil [190]. Further, biochar nanoparticles formed during biochar production and transportation can cause health hazards such as respiratory problems for humans. Correspondingly, biochar derived from rice husk and pyrolyzed at higher temperatures contains toxic crystalline substances, particularly silica, and this can affect lung health if the biochar enters the respiratory system during its application [48]. In aquatic ecosystems, biochar was shown to increase the leaching of dissolved organic carbon, and this apparently reduced the light penetration in lakes [131,191]. Finally, studies have shown that biochar application disturbed the abundance of earthworms (Lumbricus terrestris), which play a key role in soil formation, breakdown of organic matter, and nutrient cycling in agroecosystems [192].

\section{Conclusions and Perspectives}

Biochar application can have a profound impact on soil $\mathrm{pH}$, bulk density, aeration, porosity, CEC, WHC, nutrient balances, and other parameters of soil quality due to its intrinsic structure and physicochemical properties. Higher carbon and mineral content in the biochar are beneficial for improvement of soil health, fertility, and crop growth and yields. The high CEC, surface area, pore volume, and porosity of biochar can increase the WHC and ameliorate the adverse effects of soil with high concentrations of salt and heavy metals to improve crop productivity and environmental sustainability. Since most biochars have high $\mathrm{pH}$ (alkaline), there is also the potential for them to be used as an acidic soil amendment. The application of biochar can increase the microbial biomass, WUE, and NUE when applied either alone or in combination with organic and inorganic sources of fertilizers. However, this array of beneficial effects of biochar application has 
been more commonly reported in sandy soils than in clayey ones. Despite these benefits, biochar has some limitations. Potential limitations of biochar in arable soils must be taken into consideration prior its utilization. Additionally, soil and biochar interactions are not yet fully explored, and the current review provides numerous examples of both the positive and negative impacts of biochar application on soil organic carbon mineralization and microbial biomass. Furthermore, the effect of biochar application on soil properties, microbial communities, and greenhouse gas emissions in terms of future climate change is a topic that will gain much attention in future research endeavors.

A high level of nutrient retention can be predicted when using biochar as a soil amendment in the long term; thus it can improve soils. However, investigations on a large scale and a long-term use of biochar as a soil amendment are important to the prediction of the nutrient dynamics in the soils treated with such materials. Biochar application on a mass scale in extensive agriculture is expected to occur in the near future. To achieve this utmost goal, there is an urgent need for long-term assessments of the seasonal availability of main feedstocks for biochar production in the regions where biochar is intended to be used. Moreover, research studies should more frequently incorporate comprehensive economic analysis in addition to the more commonly studied implications of biochar in soil quality and plant health. Finally, while the logistic aspects of biochar distribution and further application in farmers' fields still remain a main hurdle at present, we expect these shortcomings will be increasingly and effectively addressed in the mid- to long-term.

Author Contributions: Conceptualization: M.F.S., M.L.B., A.S. Data curation: M.F.S., M.L.B., A.S. Investigation: M.F.S., M.L.B., A.S., R.S.J., H.M.A., B.A.A., K.F.A., A.M.A.-S. Resources: M.F.S., M.L.B., A.S. Software: M.F.S., A.S., R.S.J., H.M.A., B.A.A. Writing-original draft: M.F.S., M.L.B., A.S., R.S.J., B.A.A., H.M.A., K.F.A., A.M.A.-S. Writing-review and editing: M.F.S., M.L.B. All authors have read and agreed to the published version of the manuscript.

Funding: This research was funded by the Deanship of Scientific Research at Princess Nourah bint Abdulrahman University through the Fast-track Research Funding Program to support publication in the top journals (Grant no. 42-FTTJ-18).

Institutional Review Board Statement: Not applicable.

Informed Consent Statement: Not applicable.

Acknowledgments: This research was funded by the Deanship of Scientific Research at Princess Nourah bint Abdulrahman University through the Fast-track Research Funding Program to support publication in the top journals (Grant no. 42-FTTJ-18).

Conflicts of Interest: The authors declare no conflict of interest.

\section{References}

1. Diatta, A.A.; Fike, J.H.; Battaglia, M.L.; Galbraith, J.; Baig, M.B. Effects of biochar on soil fertility and crop productivity in arid regions: A review. Arab. J. Geosci. 2020, 13, 595. [CrossRef]

2. Weber, K.; Quicker, P. Properties of biochar. Fuel 2018, 217, 240-261. [CrossRef]

3. Diatta, A.A.; Thomason, W.E.; Abaye, O.; Thompson, T.L.; Battaglia, M.L.; Vaughan, L.J.; Lo, M.; Leme, J.F.D.C. Assessment of nitrogen fixation by mungbean genotypes in different soil textures using $15 \mathrm{~N}$ natural abundance method. J. Soil Sci. Plant Nutr. 2020, 20, 2230-2240. [CrossRef]

4. Adnan, M.; Fahad, S.; Zamin, M.; Shah, S.; Mian, I.A.; Danish, S.; Zafar-ul-Hye, M.; Battaglia, M.L.; Naz, R.M.M.; Saeed, B.; et al. Coupling phosphate-solubilizing bacteria with phosphorus supplements improve maize phosphorus acquisition and growth under lime induced salinity stress. Plants 2020, 9, 900. [CrossRef] [PubMed]

5. Seleiman, M.F.; Kheir, A.M.S. Maize productivity, heavy metals uptake and their availability in contaminated clay and sandy alkaline soils as affected by inorganic and organic amendments. Chemosphere 2018, 204, 514-522. [CrossRef] [PubMed]

6. Seleiman, M.F.; Alotaibi, M.A.; Alhammad, B.A.; Alharbi, B.M.; Refay, Y.; Badawy, S.A. Effects of ZnO nanoparticles and biochar of rice straw and cow manure on characteristics of contaminated soil and sunflower productivity, oil quality, and heavy metals uptake. Agronomy 2020, 10, 790. [CrossRef]

7. Seleiman, M.F.; Almutairi, K.F.; Alotaibi, M.; Shami, A.; Alhammad, B.A.; Battaglia, M.L. Nano fertilization as an emerging fertilization technique: Why modern agriculture can benefit from its use? Plants 2021, 10, 2. [CrossRef]

8. Adeyemi, O.; Keshavarz-Afshar, R.; Jahanzad, E.; Battaglia, M.L.; Luo, Y.; Sadeghpour, A. Effect of wheat cover crop and split nitrogen application on corn yield and nitrogen use efficiency. Agronomy 2020, 10, 1081. [CrossRef] 
9. Bonanomi, G.; Ippolito, F.; Cesarano, G.; Nanni, B.; Lombardi, N.; Rita, A.; Saracino, A.; Scala, F. Biochar as plant growth promoter: Better off alone or mixed with organic amendments? Front. Plant Sci. 2017, 8, 1570. [CrossRef] [PubMed]

10. Rawat, J.; Saxena, J.; Sanwal, P. Biochar: A sustainable approach for improving plant growth and soil properties. In Biochar-An Imperative Amendment for Soil and the Environment; IntechOpen: London, UK, 2019. [CrossRef]

11. Pariyar, P.; Kumari, K.; Jain, M.K.; Jadhao, P.S. Evaluation of change in biochar properties derived from different feedstock and pyrolysis temperature for environmental and agricultural application. Sci. Total Environ. 2020, 713, 136433. [CrossRef]

12. Wang, D.; Jiang, P.; Zhang, H.; Yuan, W. Biochar production and applications in agro and forestry systems: A review. Sci. Total Environ. 2020, 723, 137775. [CrossRef] [PubMed]

13. Abujabhah, I.S.D. Investigating the effect of biochar on microbial activities and biological processes in soil. Master of Sciences Thesis, University of Tasmania, Hobart, Australia, 2017.

14. Seleiman, M.F.; Hafez, E.M. Optimizing Inputs Management for Sustainable Agricultural Development. In Mitigating Environmental Stresses for Agricultural Sustainability in Egypt; Springer Water; Springer: Cham, Switzerland, 2021; pp. $487-507$. [CrossRef]

15. Inyang, M.; Dickenson, E. The potential role of biochar in the removal of organic and microbial contaminants from potable and reuse water: A review. Chemosphere 2015, 134, 232-240. [CrossRef] [PubMed]

16. Gao, S.; DeLuca, T.H. Influence of biochar on soil nutrient transformations, nutrient leaching, and crop yield. Adv. Plants Agric. Res. 2016, 4, 348-362.

17. Tomczyk, A.; Sokołowska, Z.; Boguta, P. Biochar physicochemical properties: Pyrolysis temperature and feedstock kind effects. Rev. Environ. Sci. Biotechnol. 2020, 19, 191-215. [CrossRef]

18. Kavitha, B.; Reddy, P.V.L.; Kim, B.; Lee, S.S.; Pandey, S.K.; Kim, K.H. Benefits and limitations of biochar amendment in agricultural soils: A review. J. Environ. Manag. 2018, 227, 146-154. [CrossRef] [PubMed]

19. Igalavithana, A.D.; Mandal, S.; Niazi, N.K.; Vithanage, M.; Parikh, S.J.; Mukome, F.N.D.; Rizwan, M.; Oleszczuk, P.; Al-Wabel, M.; Bolan, N. Advances and future directions of biochar characterization methods and applications. Crit. Rev. Environ. Sci. Technol. 2017, 47, 2275-2330. [CrossRef]

20. Shakya, A.; Agarwal, T. Potential of Biochar for the Remediation of Heavy Metal Contaminated Soil. In Biochar Applications in Agriculture and Environment Management; Springer: Berlin/Heidelberg, Germany, 2020; pp. 77-98.

21. Zhao, B.; O'Connor, D.; Zhang, J.; Peng, T.; Shen, Z.; Tsang, D.C.W.; Hou, D. Effect of pyrolysis temperature, heating rate, and residence time on rapeseed stem derived biochar. J. Clean. Prod. 2018, 174, 977-987. [CrossRef]

22. Lu, S.; Zong, Y. Pore structure and environmental serves of biochars derived from different feedstocks and pyrolysis conditions. Environ. Sci. Pollut. Res. 2018, 25, 30401-30409. [CrossRef]

23. Blanco-Canqui, H. Biochar and soil physical properties. Soil Sci. Soc. Am. J. 2017, 81, 687-711. [CrossRef]

24. de Jesus Duarte, S.; Glaser, B.; Cerri, C.E.P. Effect of biochar particle size on physical, hydrological and chemical properties of loamy and sandy tropical soils. Agronomy 2019, 9, 165. [CrossRef]

25. Yao, Q.; Liu, J.; Yu, Z.; Li, Y.; Jin, J.; Liu, X.; Wang, G. Three years of biochar amendment alters soil physiochemical properties and fungal community composition in a black soil of Northeast China. Soil Biol. Biochem. 2017, 110, 56-67. [CrossRef]

26. Kameyama, K.; Miyamoto, T.; Iwata, Y. The preliminary study of water-retention related properties of biochar produced from various feedstock at different pyrolysis temperatures. Materials 2019, 12, 1732. [CrossRef] [PubMed]

27. Mao, J.; Zhang, K.; Chen, B. Linking hydrophobicity of biochar to the water repellency and water holding capacity of biocharamended soil. Environ. Pollut. 2019, 253, 779-789. [CrossRef] [PubMed]

28. Novotny, E.H.; de Freitas Maia, C.M.; de Melo Carvalho, M.T.; Madari, B.E. Biochar: Pyrogenic carbon for agricultural use-a critical review. Rev. Bras. Ciênc. Solo 2015, 39, 321-344. [CrossRef]

29. Dai, L.; Fan, L.; Liu, Y.; Ruan, R.; Wang, Y.; Zhou, Y.; Zhao, Y.; Yu, Z. Production of bio-oil and biochar from soapstock via microwave-assisted co-catalytic fast pyrolysis. Bioresour. Technol. 2017, 225, 1-8. [CrossRef] [PubMed]

30. Singh, C.; Tiwari, S.; Singh, J.S. Biochar: A sustainable tool in soil pollutant bioremediation. In Bioremediation of Industrial Waste for Environmental Safety; Springer: Berlin/Heidelberg, Germany, 2020; pp. 475-494.

31. Aller, M.F. Biochar properties: Transport, fate, and impact. Crit. Rev. Environ. Sci. Technol. 2016, 46, 1183-1296. [CrossRef]

32. Palansooriya, K.N.; Wong, J.T.F.; Hashimoto, Y.; Huang, L.; Rinklebe, J.; Chang, S.X.; Bolan, N.; Wang, H.; Ok, Y.S. Response of microbial communities to biochar-amended soils: A critical review. Biochar 2019, 1, 3-22. [CrossRef]

33. Palansooriya, K.N.; Ok, Y.S.; Awad, Y.M.; Lee, S.S.; Sung, J.-K.; Koutsospyros, A.; Moon, D.H. Impacts of biochar application on upland agriculture: A review. J. Environ. Manag. 2019, 234, 52-64. [CrossRef]

34. Suliman, W.; Harsh, J.B.; Abu-Lail, N.I.; Fortuna, A.-M.; Dallmeyer, I.; Garcia-Perez, M. Influence of feedstock source and pyrolysis temperature on biochar bulk and surface properties. Biomass Bioenergy 2016, 84, 37-48. [CrossRef]

35. Cely, P.; Gascó, G.; Paz-Ferreiro, J.; Méndez, A. Agronomic properties of biochars from different manure wastes. J. Anal. Appl. Pyrolysis 2015, 111, 173-182. [CrossRef]

36. Zaman, C.Z.; Pal, K.; Yehye, W.A.; Sagadevan, S.; Shah, S.T.; Adebisi, G.A.; Marliana, E.; Rafique, R.F.; Johan, R. Bin. Pyrolysis: A sustainable way to generate energy from waste. In Pyrolysis; BoD-Books on Demand: Norderstedt, Germany, 2017 ; p. 1.

37. Naeem, M.; Ansari, A.A.; Gill, S.S. Essential plant nutrients: Uptake, use efficiency, and management. Essent. Plant Nutr. Uptake Use Effic. Manag. 2017, 1-569. [CrossRef] 
38. Xu, Y.; Qi, F.; Bai, T.; Yan, Y.; Wu, C.; An, Z.; Luo, S.; Huang, Z.; Xie, P. A further inquiry into co-pyrolysis of straws with manures for heavy metal immobilization in manure-derived biochars. J. Hazard. Mater. 2019, 380, 120870. [CrossRef] [PubMed]

39. Hassan, M.; Liu, Y.; Naidu, R.; Parikh, S.J.; Du, J.; Qi, F.; Willett, I.R. Influences of feedstock sources and pyrolysis temperature on the properties of biochar and functionality as adsorbents: A meta-analysis. Sci. Total Environ. 2020, 744, 140714. [CrossRef] [PubMed]

40. Jafri, N.; Wong, W.Y.; Doshi, V.; Yoon, L.W.; Cheah, K.H. A review on production and characterization of biochars for application in direct carbon fuel cells. Process Saf. Environ. Prot. 2018, 118, 152-166. [CrossRef]

41. El-Naggar, A.; El-Naggar, A.H.; Shaheen, S.M.; Sarkar, B.; Chang, S.X.; Tsang, D.C.W.; Rinklebe, J.; Ok, Y.S. Biochar compositiondependent impacts on soil nutrient release, carbon mineralization, and potential environmental risk: A review. J. Environ. Manag. 2019, 241, 458-467. [CrossRef]

42. Gul, S.; Whalen, J.K.; Thomas, B.W.; Sachdeva, V.; Deng, H. Physico-chemical properties and microbial responses in biocharamended soils: Mechanisms and future directions. Agric. Ecosyst. Environ. 2015, 206, 46-59. [CrossRef]

43. Omotade, I.; Momoh, S.; Oluwafemi, B.; Agboola, E. Comparative analysis of nutrients composition in biochar produced from different feedstocks at varying pyrolysis temperature. Environ. Res. Technol. 2020, 3, 64-70. [CrossRef]

44. Wang, D.; Fonte, S.J.; Parikh, S.J.; Six, J.; Scow, K.M. Biochar additions can enhance soil structure and the physical stabilization of $\mathrm{C}$ in aggregates. Geoderma 2017, 303, 110-117. [CrossRef]

45. Ippolito, J.A.; Cui, L.; Kammann, C.; Wrage-Mönnig, N.; Estavillo, J.M.; Fuertes-Mendizabal, T.; Cayuela, M.L.; Sigua, G.; Novak, J.; Spokas, K.; et al. Feedstock choice, pyrolysis temperature and type influence biochar characteristics: A comprehensive meta-data analysis review. Biochar 2020, 2, 421-438. [CrossRef]

46. Amoah-Antwi, C.; Kwiatkowska-Malina, J.; Szara, E.; Thornton, S.; Fenton, O.; Malina, G. Efficacy of woodchip biochar and brown coal waste as stable sorbents for abatement of bioavailable cadmium, lead and zinc in soil. Water Air Soil Pollut. 2020, 231, 1-17. [CrossRef]

47. Ippolito, J.A.; Spokas, K.A.; Novak, J.M.; Lentz, R.D.; Cantrell, K.B. Biochar elemental composition and factors influencing nutrient retention. In Biochar for Environmental Management: Science, Technology and Implementation; Springer: Berlin/Heidelberg, Germany, 2015; pp. 139-163.

48. Hussain, M.; Farooq, M.; Nawaz, A.; Al-Sadi, A.M.; Solaiman, Z.M.; Alghamdi, S.S.; Ammara, U.; Ok, Y.S.; Siddique, K.H.M. Biochar for crop production: Potential benefits and risks. J. Soils Sediments 2017, 17, 685-716. [CrossRef]

49. Yadav, V.; Khare, P. Impact of pyrolysis techniques on biochar characteristics: Application to soil. In Biochar Applications in Agriculture and Environment Management; Springer: Berlin/Heidelberg, Germany, 2020; pp. 33-52.

50. Gabhane, J.W.; Bhange, V.P.; Patil, P.D.; Bankar, S.T.; Kumar, S. Recent trends in biochar production methods and its application as a soil health conditioner: A review. SN Appl. Sci. 2020, 2, 1-21. [CrossRef]

51. Thines, K.R.; Abdullah, E.C.; Mubarak, N.M.; Ruthiraan, M. Synthesis of magnetic biochar from agricultural waste biomass to enhancing route for waste water and polymer application: A review. Renew. Sustain. Energy Rev. 2017, 67, 257-276. [CrossRef]

52. Gholizadeh, M.; Li, C.; Zhang, S.; Wang, Y.; Niu, S.; Li, Y.; Hu, X. Progress of the development of reactors for pyrolysis of municipal waste. Sustain. Energy Fuels 2020, 4, 5885-5915. [CrossRef]

53. Brassard, P.; Godbout, S.; Lévesque, V.; Palacios, J.H.; Raghavan, V.; Ahmed, A.; Hogue, R.; Jeanne, T.; Verma, M. Biochar for Soil Amendment; Springer: Berlin/Heidelberg, Germany, 2019. [CrossRef]

54. Jouhara, H.; Ahmad, D.; van den Boogaert, I.; Katsou, E.; Simons, S.; Spencer, N. Pyrolysis of domestic based feedstock at temperatures up to $300^{\circ} \mathrm{C}$. Therm. Sci. Eng. Prog. 2018, 5, 117-143. [CrossRef]

55. Amini, S.; Ghadiri, H.; Chen, C.; Marschner, P. Salt-affected soils, reclamation, carbon dynamics, and biochar: A review. J. Soils Sediments 2016, 16, 939-953. [CrossRef]

56. Choi, J.H.; Kim, S.-S.; Ly, H.V.; Kim, J.; Woo, H.C. Effects of water-washing saccharina japonica on fast pyrolysis in a bubbling fluidized-bed reactor. Biomass Bioenergy 2017, 98, 112-123. [CrossRef]

57. Méndez, A.; Paz-Ferreiro, J.; Gil, E.; Gascó, G. The effect of paper sludge and biochar addition on brown peat and coir based growing media properties. Sci. Hortic. 2015, 193, 225-230. [CrossRef]

58. Veses, A.; Aznar, M.; López, J.M.; Callén, M.S.; Murillo, R.; García, T. Production of upgraded bio-oils by biomass catalytic pyrolysis in an auger reactor using low cost materials. Fuel 2015, 141, 17-22. [CrossRef]

59. Guda, V.K.; Steele, P.H.; Penmetsa, V.K.; Li, Q. Fast Pyrolysis of Biomass: Recent Advances in Fast Pyrolysis Technology; Elsevier: Amsterdam, The Netherlands, 2015. [CrossRef]

60. Matayeva, A.; Basile, F.; Cavani, F.; Bianchi, D.; Chiaberge, S. Development of upgraded bio-oil via liquefaction and pyrolysis. In Studies in Surface Science and Catalysis; Elsevier: Amsterdam, The Netherlands, 2019; Volume 178, pp. 231-256.

61. Pecha, M.B.; Garcia-Perez, M. Pyrolysis of lignocellulosic biomass: Oil, char, and gas. In Bioenergy; Elsevier: Amsterdam, The Netherlands, 2020; pp. 581-619.

62. Pattiya, A. 1-Fast Pyrolysis; Elsevier Ltd.: Amsterdam, The Netherlands, 2018. [CrossRef]

63. Zhang, C.; Lin, Y.; Tian, X.; Xu, Q.; Chen, Z.; Lin, W. Tobacco bacterial wilt suppression with biochar soil addition associates to improved soil physiochemical properties and increased rhizosphere bacteria abundance. Appl. Soil Ecol. 2017, 112, 90-96. [CrossRef]

64. Benedetti, V.; Patuzzi, F.; Baratieri, M. Characterization of char from biomass gasification and its similarities with activated carbon in adsorption applications. Appl. Energy 2018, 227, 92-99. [CrossRef] 
65. You, S.; Ok, Y.S.; Chen, S.S.; Tsang, D.C.W.; Kwon, E.E.; Lee, J.; Wang, C.H. A critical review on sustainable biochar system through gasification: Energy and environmental applications. Bioresour. Technol. 2017, 246, 242-253. [CrossRef]

66. Choudhury, H.A.; Chakma, S.; Moholkar, V.S. Biomass gasification integrated fischer-tropsch synthesis: Perspectives, opportunities and challenges. In Recent Advances in Thermo-Chemical Conversion of Biomass; Elsevier: Amsterdam, The Netherlands, 2015; pp. 383-435.

67. Yao, Z.; You, S.; Ge, T.; Wang, C.-H. Biomass Gasification for syngas and biochar co-production: Energy application and economic evaluation. Appl. Energy 2018, 209, 43-55. [CrossRef]

68. Muvhiiwa, R.; Kuvarega, A.; Llana, E.M.; Muleja, A. Study of biochar from pyrolysis and gasification of wood pellets in a nitrogen plasma reactor for design of biomass processes. J. Environ. Chem. Eng. 2019, 7, 103391. [CrossRef]

69. Barskov, S.; Zappi, M.; Buchireddy, P.; Dufreche, S.; Guillory, J.; Gang, D.; Hernandez, R.; Bajpai, R.; Baudier, J.; Cooper, R. Torrefaction of biomass: A review of production methods for biocoal from cultured and waste lignocellulosic feedstocks. Renew. Energy 2019, 142, 624-642. [CrossRef]

70. Pathomrotsakun, J.; Nakason, K.; Kraithong, W.; Khemthong, P.; Panyapinyopol, B.; Pavasant, P. Fuel properties of biochar from torrefaction of ground coffee residue: Effect of process temperature, time, and sweeping gas. Biomass Convers. Biorefinery 2020, 10, 1-11. [CrossRef]

71. Sushant, N.; Gaurav, J.; Kali, D.; Koushik, M.; Sasikumar, E.; Roy, J.K. Torrefaction: A sustainable method for transforming of agri-wastes to high energy density solids (biocoal). Rev. Environ. Sci. Bio/Technol. 2020, 19, 463-488.

72. Stępień, P.; Pulka, J.; Białowiec, A. Organic waste torrefaction-A review: Reactor systems, and the biochar properties. Pyrolysis 2017, 37. [CrossRef]

73. Liu, Z.; Hoekman, S.K.; Balasubramanian, R.; Zhang, F.-S. Improvement of fuel qualities of solid fuel biochars by washing treatment. Fuel Process. Technol. 2015, 134, 130-135. [CrossRef]

74. Zhang, J.; Zhang, J.; Wang, M.; Wu, S.; Wang, H.; Niazi, N.K.; Man, Y.B.; Christie, P.; Shan, S.; Wong, M.H. Effect of tobacco stem-derived biochar on soil metal immobilization and the cultivation of tobacco plant. J. Soils Sediments 2019, 19, $2313-2321$. [CrossRef]

75. Kumar, P.; Lai, L.; Battaglia, M.L.; Kumar, S.; Owens, V.; Fike, J.; Galbraith, J.; Hong, C.O.; Faris, R.; Crawford, R.; et al. Impacts of nitrogen fertilization rate and landscape position on select soil properties in switchgrass field at four sites in the USA. Catena 2019, 180, 183-193. [CrossRef]

76. Purakayastha, T.J.; Bera, T.; Bhaduri, D.; Sarkar, B.; Mandal, S.; Wade, P.; Kumari, S.; Biswas, S.; Menon, M.; Pathak, H. A review on biochar modulated soil condition improvements and nutrient dynamics concerning crop yields: Pathways to climate change mitigation and global food security. Chemosphere 2019, 227, 345-365. [CrossRef] [PubMed]

77. Adekiya, A.O.; Agbede, T.M.; Olayanju, A.; Ejue, W.S.; Adekanye, T.A.; Adenusi, T.T.; Ayeni, J.F. Effect of biochar on soil properties, soil loss, and cocoyam yield on a tropical sandy loam alfisol. Sci. World J. 2020, 2020. [CrossRef]

78. Alghamdi, A.G. Biochar as a potential soil additive for improving soil physical properties-a review. Arab. J. Geosci. 2018, 11. [CrossRef]

79. Razzaghi, F.; Obour, P.B.; Arthur, E. Does biochar improve soil water retention? A systematic review and meta-analysis. Geoderma 2020, 361, 114055. [CrossRef]

80. Mclennon, E.; Solomon, J.K.Q.; Neupane, D.; Davison, J. Biochar and nitrogen application rates effect on phosphorus removal from a mixed grass sward irrigated with reclaimed wastewater. Sci. Total Environ. 2020, 715, 137012. [CrossRef]

81. Liu, Z.; Dugan, B.; Masiello, C.A.; Gonnermann, H.M. Biochar particle size, shape, and porosity act together to influence soil water properties. PLoS ONE 2017, 12, 1-19. [CrossRef] [PubMed]

82. Kätterer, T.; Roobroeck, D.; Andrén, O.; Kimutai, G.; Karltun, E.; Kirchmann, H.; Nyberg, G.; Vanlauwe, B.; Röing de Nowina, K. Biochar addition persistently increased soil fertility and yields in maize-soybean rotations over 10 years in sub-humid regions of Kenya. Field Crop. Res. 2019, 235, 18-26. [CrossRef]

83. Ndor, E.; Jayeoba, O.J.; Asadu, C.L.A. Effect of biochar soil amendment on soil properties and yield of sesame varieties in Lafia, Nigeria. J. Exp. Agric. Int. 2015, 9, 1-8. [CrossRef]

84. Are, K.S. Biochar and Soil Physical Health. In Biochar-An Imperative Amendment for Soil and the Environment; IntechOpen: London, UK, 2019; pp. 21-33. [CrossRef]

85. Battaglia, M.L.; Thomason, W.E.; Fike, J.H.; Evanylo, G.; von Cossel, M.; Babur, E.; Iqbal, Y.; Diatta, A. The broad impacts of corn stover and wheat straw removal on crop productivity, soil health and greenhouse gases emissions: A review. GCB Bioenergy 2021, 13, 45-57. [CrossRef]

86. El-Naggar, A.; Lee, S.S.; Awad, Y.M.; Yang, X.; Ryu, C.; Rizwan, M.; Rinklebe, J.; Tsang, D.C.W.; Ok, Y.S. Influence of soil properties and feedstocks on biochar potential for carbon mineralization and improvement of infertile soils. Geoderma 2018, 332, 100-108. [CrossRef]

87. Yang, C.D.; Lu, S.G. Dynamic effects of direct returning of straw and corresponding biochar on acidity, nutrients, and exchangeable properties of red soil. Huan Jing Xue Huanjing Kexue 2020, 41, 4246-4252.

88. Lévesque, V.; Rochette, P.; Ziadi, N.; Dorais, M.; Antoun, H. Mitigation of $\mathrm{CO}_{2}, \mathrm{CH}_{4}$ and $\mathrm{N}_{2} \mathrm{O}$ from a fertigated horticultural growing medium amended with biochars and a compost. Appl. Soil Ecol. 2018, 126, 129-139. [CrossRef]

89. Jiang, X.; Haddix, M.L.; Cotrufo, M.F. Interactions between biochar and soil organic carbon decomposition: Effects of nitrogen and low molecular weight carbon compound addition. Soil Biol. Biochem. 2016, 100, 92-101. [CrossRef] 
90. Omondi, M.O.; Xia, X.; Nahayo, A.; Liu, X.; Korai, P.K.; Pan, G. Quantification of biochar effects on soil hydrological properties using meta-analysis of literature data. Geoderma 2016, 274, 28-34. [CrossRef]

91. DeLuca, T.H.; Gundale, M.J.; MacKenzie, M.D.; Jones, D.L. Biochar effects on soil nutrient transformations. Biochar Environ. Manag. Sci. Technol. Implement. 2015, 2, 421-454.

92. Tian, S.; Tan, Z.; Kasiulienè, A.; Ai, P. Transformation mechanism of nutrient elements in the process of biochar preparation for returning biochar to soil. Chin. J. Chem. Eng. 2017, 25, 477-486. [CrossRef]

93. Martinsen, V.; Alling, V.; Nurida, N.L.; Mulder, J.; Hale, S.E.; Ritz, C.; Rutherford, D.W.; Heikens, A.; Breedveld, G.D.; Cornelissen, G. PH effects of the addition of three biochars to acidic indonesian mineral soils. Soil Sci. Plant Nutr. 2015, 61, 821-834. [CrossRef]

94. Chathurika, J.A.S.; Kumaragamage, D.; Zvomuya, F.; Akinremi, O.O.; Flaten, D.N.; Indraratne, S.P.; Dandeniya, W.S. Woodchip biochar with or without synthetic fertilizers affects soil properties and available phosphorus in two alkaline, chernozemic soils. Can. J. Soil Sci. 2016, 96, 472-484. [CrossRef]

95. Sandhu, S.S.; Ussiri, D.A.N.; Kumar, S.; Chintala, R.; Papiernik, S.K.; Malo, D.D.; Schumacher, T.E. Analyzing the impacts of three types of biochar on soil carbon fractions and physiochemical properties in a corn-soybean rotation. Chemosphere 2017, 184, 473-481. [CrossRef]

96. Gao, L.; Wang, R.; Shen, G.; Zhang, J.; Meng, G.; Zhang, J. Effects of biochar on nutrients and the microbial community structure of tobacco-planting soils. J. Soil Sci. Plant Nutr. 2017, 17, 884-896. [CrossRef]

97. Karimi, A.; Moezzi, A.; Chorom, M.; Enayatizamir, N. Application of biochar changed the status of nutrients and biological activity in a calcareous soil. J. Soil Sci. Plant Nutr. 2020, 20, 450-459. [CrossRef]

98. Pandit, N.R.; Mulder, J.; Hale, S.E.; Martinsen, V.; Schmidt, H.P.; Cornelissen, G. Biochar improves maize growth by alleviation of nutrient stress in a moderately acidic low-input nepalese soil. Sci. Total Environ. 2018, 625, 1380-1389. [CrossRef] [PubMed]

99. Deng, B.; Tammeorg, P.; Luukkanen, O.; Helenius, J.; Starr, M. Effects of acacia seyal and biochar on soil properties and sorghum yield in agroforestry systems in South Sudan. Agrofor. Syst. 2017, 91, 137-148. [CrossRef]

100. Mousa, A.A.A. Effect of using some soil conditioners on salt affected soil properties and its productivity at El-Tina Plain Area, North Sinai, Egypt. Egypt. J. Soil Sci. 2017, 57, 101-111. [CrossRef]

101. Yang, X.; Meng, J.; Lan, Y.; Chen, W.; Yang, T.; Yuan, J.; Liu, S.; Han, J. Effects of maize stover and its biochar on soil $\mathrm{CO}_{2}$ emissions and labile organic carbon fractions in Northeast China. Agric. Ecosyst. Environ. 2017, 240, 24-31. [CrossRef]

102. Arif, M.; Ilyas, M.; Riaz, M.; Ali, K.; Shah, K.; Haq, I.U.; Fahad, S. Biochar improves phosphorus use efficiency of organic-inorganic fertilizers, maize-wheat productivity and soil quality in a low fertility alkaline soil. Field Crop. Res. 2017, 214, 25-37. [CrossRef]

103. Usman, A.R.A.; Al-Wabel, M.I.; Abdulaziz, A.-H.; Mahmoud, W.-A.; El-Naggar, A.H.; Ahmad, M.; Abdulelah, A.-F.; Abdulrasoul, A.-O. Conocarpus biochar induces changes in soil nutrient availability and tomato growth under saline irrigation. Pedosphere 2016, 26, 27-38. [CrossRef]

104. Amer, M.M. Effect of biochar, compost tea and magnetic iron ore application on some soil properties and productivity of some field crops under saline soils conditions at North Nile Delta. Egypt. J. Soil Sci. 2017, 56, 169-186. [CrossRef]

105. Kim, H.-S.; Kim, K.-R.; Yang, J.E.; Ok, Y.S.; Owens, G.; Nehls, T.; Wessolek, G.; Kim, K.-H. Effect of biochar on reclaimed tidal land soil properties and maize (Zea Mays L.) response. Chemosphere 2016, 142, 153-159. [CrossRef]

106. Xiao, Q.; Zhu, L.-X.; Zhang, H.-P.; Li, X.-Y.; Shen, Y.-F.; Li, S.-Q. Soil amendment with biochar increases maize yields in a semi-arid region by improving soil quality and root growth. Crop Pasture Sci. 2016, 67, 495-507. [CrossRef]

107. Akhtar, S.S.; Andersen, M.N.; Liu, F. Residual effects of biochar on improving growth, physiology and yield of wheat under salt stress. Agric. Water Manag. 2015, 158, 61-68. [CrossRef]

108. Badr, E.A.; Ibrahim, O.M.; Tawfik, M.M.; Bahr, A.A. Management strategy for improving the productivity of wheat in newly reclaimed sandy soil. Inter. J. Chem. Technol. Res. 2015, 8, 1438-1445.

109. Akhtar, S.S.; Andersen, M.N.; Liu, F. Biochar mitigates salinity stress in potato. J. Agronom. Crop Sci. 2015, 201, 368-378. [CrossRef]

110. Nabavinia, F.; Emami, H.; Astaraee, A.; Lakzian, A. Effect of tannery wastes and biochar on soil chemical and physicochemical properties and growth traits of radish. Int. Agrophysics 2015, 29, 333-339. [CrossRef]

111. Lashari, M.S.; Ye, Y.; Ji, H.; Li, L.; Kibue, G.W.; Lu, H.; Zheng, J.; Pan, G. Biochar-manure compost in conjunction with pyroligneous solution alleviated salt stress and improved leaf bioactivity of maize in a saline soil from Central China: A 2-year field experiment. J. Sci. Food Agric. 2015, 95, 1321-1327. [CrossRef]

112. Agegnehu, G.; Bass, A.M.; Nelson, P.N.; Bird, M.I. Benefits of biochar, compost and biochar-compost for soil quality, maize yield and greenhouse gas emissions in a tropical agricultural soil. Sci. Total Environ. 2016, 543, 295-306. [CrossRef]

113. Sigua, G.C.; Novak, J.M.; Watts, D.W.; Johnson, M.G.; Spokas, K. Efficacies of designer biochars in improving biomass and nutrient uptake of winter wheat grown in a hard setting subsoil layer. Chemosphere 2016, 142, 176-183. [CrossRef]

114. Liu, Y.; Lonappan, L.; Brar, S.K.; Yang, S. Impact of biochar amendment in agricultural soils on the sorption, desorption, and degradation of pesticides: A review. Sci. Total Environ. 2018, 645, 60-70. [CrossRef]

115. El-Naggar, A.H.; Usman, A.R.A.; Al-Omran, A.; Ok, Y.S.; Ahmad, M.; Al-Wabel, M.I. Carbon mineralization and nutrient availability in calcareous sandy soils amended with woody waste biochar. Chemosphere 2015, 138, 67-73. [CrossRef]

116. De Figueredo, N.A.; da Costa, L.M.; Melo, L.C.A.; Siebeneichlerd, E.A.; Tronto, J. Characterization of biochars from different sources and evaluation of release of nutrients and contaminants. Rev. Ciênc. Agronôm. 2017, 48, 3-403. [CrossRef]

117. Rubin, R.L.; Anderson, T.R.; Ballantine, K.A. Biochar simultaneously reduces nutrient leaching and greenhouse gas emissions in restored wetland soils. Wetlands 2020, 11, 1-11. [CrossRef] 
118. Xu, N.; Tan, G.; Wang, H.; Gai, X. Effect of biochar additions to soil on nitrogen leaching, microbial biomass and bacterial community structure. Eur. J. Soil Biol. 2016, 74, 1-8. [CrossRef]

119. Sun, H.; Lu, H.; Chu, L.; Shao, H.; Shi, W. Biochar applied with appropriate rates can reduce $\mathrm{N}$ leaching, keep $\mathrm{N}$ retention and not increase NH3 volatilization in a coastal saline soil. Sci. Total Environ. 2017, 575, 820-825. [CrossRef]

120. Rizwan, M.; Ali, S.; Zia ur Rehman, M.; Adrees, M.; Arshad, M.; Qayyum, M.F.; Ali, L.; Hussain, A.; Chatha, S.A.S.; Imran, M. Alleviation of cadmium accumulation in maize (Zea Mays L.) by foliar spray of zinc oxide nanoparticles and biochar to contaminated soil. Environ. Pollut. 2019, 248, 358-367. [CrossRef]

121. Kirchman, D.L. Processes in Microbial Ecology; Oxford University Press: Oxford, UK, 2018.

122. Zhu, X.; Chen, B.; Zhu, L.; Xing, B. Effects and mechanisms of biochar-microbe interactions in soil improvement and pollution remediation: A review. Environ. Pollut. 2017, 227, 98-115. [CrossRef]

123. Rodríguez-Vila, A.; Forján, R.; Guedes, R.S.; Covelo, E.F. Changes on the phytoavailability of nutrients in a mine soil reclaimed with compost and biochar. Water Air Soil Pollut. 2016, 227, 453. [CrossRef]

124. Jaafar, N.M.; Clode, P.L.; Abbott, L.K. Biochar-soil interactions in four agricultural soils. Pedosphere 2015, 25, 729-736. [CrossRef]

125. Seleiman, M.F.; Refay, Y.; Al-Suhaibani, N.; Al-Ashkar, I.; El-Hendawy, S.; Hafez, E.M. Integrative effects of rice-straw biochar and silicon on oil and seed quality, yield and physiological traits of Helianthus Annuus L. Grown under water deficit stress. Agronomy 2019, 9, 637. [CrossRef]

126. Taha, R.S.; Seleiman, M.F.; Alotaibi, M.; Alhammad, B.A.; Rady, M.M.; Mahdi, A.H.A. Exogenous potassium treatments elevate salt tolerance and performances of glycine max L. by boosting antioxidant defense system under actual saline field conditions. Agronomy 2020, 10, 1741. [CrossRef]

127. Seleiman, M.F.; Al-Suhaibani, N.; Ali, N.; Akmal, M.; Alotaibi, M.; Refay, Y.; Dindaroglu, T.; Haleem, H.; Battaglia, M.L. Drought stress impacts on plants and different approaches to alleviate its adverse effects. Plants 2021, 10, 259. [CrossRef] [PubMed]

128. Ding, Z.; Kheir, A.S.; Ali, O.A.; Hafez, E.; Elshamey, E.A.; Zhou, Z.; Wang, B.; Lin, X.; Ge, Y.; Fahmy, A.F.; et al. Vermicompost and deep tillage system to improve saline-sodic soil quality and wheat productivity. J. Environ. Manag. 2020, 277, 111388. [CrossRef] [PubMed]

129. Zheng, H.; Wang, X.; Chen, L.; Wang, Z.; Xia, Y.; Zhang, Y.; Wang, H.; Luo, X.; Xing, B. Enhanced growth of halophyte plants in biochar-amended coastal soil: Roles of nutrient availability and rhizosphere microbial modulation. Plant. Cell Environ. 2018, 41, 517-532. [CrossRef] [PubMed]

130. Lin, X.W.; Xie, Z.B.; Zheng, J.Y.; Liu, Q.; Bei, Q.C.; Zhu, J.G. Effects of biochar application on greenhouse gas emissions, carbon sequestration and crop growth in coastal saline soil. Eur. J. Soil Sci. 2015, 66, 329-338. [CrossRef]

131. Liu, C.; Wang, H.; Li, P.; Xian, Q.; Tang, X. Biochar's impact on dissolved organic matter (DOM) export from a cropland soil during natural rainfalls. Sci. Total Environ. 2019, 650, 1988-1995. [CrossRef]

132. Mandal, S.; Thangarajan, R.; Bolan, N.S.; Sarkar, B.; Khan, N.; Ok, Y.S.; Naidu, R. Biochar-induced concomitant decrease in ammonia volatilization and increase in nitrogen use efficiency by wheat. Chemosphere 2016, 142, 120-127. [CrossRef]

133. Esfandbod, M.; Phillips, I.R.; Miller, B.; Rashti, M.R.; Lan, Z.M.; Srivastava, P.; Singh, B.; Chen, C.R. Aged acidic biochar increases nitrogen retention and decreases ammonia volatilization in alkaline bauxite residue sand. Ecol. Eng. 2017, 98, 157-165. [CrossRef]

134. Meng, J.; Tao, M.; Wang, L.; Liu, X.; Xu, J. Changes in heavy metal bioavailability and speciation from a Pb-Zn mining soil amended with biochars from Co-pyrolysis of rice straw and swine manure. Sci. Total Environ. 2018, 633, 300-307. [CrossRef]

135. Cheng, S.; Chen, T.; Xu, W.; Huang, J.; Jiang, S.; Yan, B. Application research of biochar for the remediation of soil heavy metals contamination: A review. Molecules 2020, 25, 3167. [CrossRef]

136. Yu, Z.; Qiu, W.; Wang, F.; Lei, M.; Wang, D.; Song, Z. Effects of manganese oxide-modified biochar composites on arsenic speciation and accumulation in an indica rice (Oryza Sativa L.) cultivar. Chemosphere 2017, 168, 341-349. [CrossRef]

137. Sizmur, T.; Fresno, T.; Akgül, G.; Frost, H.; Moreno-Jiménez, E. Biochar modification to enhance sorption of inorganics from water. Bioresour. Technol. 2017, 246, 34-47. [CrossRef] [PubMed]

138. Beesley, L.; Moreno-Jimenez, E.; Fellet, G.; Carrijo, L.; Sizmur, T. Biochar and heavy metals. In Biochar for Environmental Management; Springer: Berlin/Heidelberg, Germany, 2015.

139. Inyang, M.I.; Gao, B.; Yao, Y.; Xue, Y.; Zimmerman, A.; Mosa, A.; Pullammanappallil, P.; Ok, Y.S.; Cao, X. A review of biochar as a low-cost adsorbent for aqueous heavy metal removal. Crit. Rev. Environ. Sci. Technol. 2016, 46, 406-433. [CrossRef]

140. Nejad, Z.D.; Jung, M.C. The effects of biochar and inorganic amendments on soil remediation in the presence of hyperaccumulator plant. Int. J. Energy Environ. Eng. 2017, 8, 317-329. [CrossRef]

141. Wang, M.; Zhu, Y.; Cheng, L.; Andserson, B.; Zhao, X.; Wang, D.; Ding, A. Review on utilization of biochar for metal-contaminated soil and sediment remediation. J. Environ. Sci. 2018, 63, 156-173. [CrossRef]

142. Penido, E.S.; Martins, G.C.; Mendes, T.B.M.; Melo, L.C.A.; do Rosário Guimarães, I.; Guilherme, L.R.G. Combining biochar and sewage sludge for immobilization of heavy metals in mining soils. Ecotoxicol. Environ. Saf. 2019, 172, 326-333. [CrossRef] [PubMed]

143. Meier, S.; Curaqueo, G.; Khan, N.; Bolan, N.; Cea, M.; Eugenia, G.M.; Cornejo, P.; Ok, Y.S.; Borie, F. Chicken-manure-derived biochar reduced bioavailability of copper in a contaminated soil. J. Soils Sediments 2017, 17, 741-750. [CrossRef]

144. Li, G.; Khan, S.; Ibrahim, M.; Sun, T.-R.; Tang, J.-F.; Cotner, J.B.; Xu, Y.-Y. Biochars Induced modification of dissolved organic matter (DOM) in soil and its impact on mobility and bioaccumulation of arsenic and cadmium. J. Hazard. Mater. 2018, 348, 100-108. [CrossRef] [PubMed] 
145. Zhao, J.; Ren, T.; Zhang, Q.; Du, Z.; Wang, Y. Effects of biochar amendment on soil thermal properties in the North China Plain. Soil Sci. Soc. Am. J. 2016, 80, 1157-1166. [CrossRef]

146. Zheng, R.; Chen, Z.; Cai, C.; Tie, B.; Liu, X.; Reid, B.J.; Huang, Q.; Lei, M.; Sun, G.; Baltrènaite, E. Mitigating heavy metal accumulation into rice (Oryza Sativa L.) using biochar amendment-a field experiment in Hunan, China. Environ. Sci. Pollut. Res. 2015, 22, 11097-11108. [CrossRef] [PubMed]

147. Fresno, T.; Moreno-Jiménez, E.; Zornoza, P.; Peñalosa, J.M. Aided phytostabilisation of As-and Cu-contaminated soils using white lupin and combined iron and organic amendments. J. Environ. Manag. 2018, 205, 142-150. [CrossRef]

148. Coumar, M.V.; Parihar, R.S.; Dwivedi, A.K.; Saha, J.K.; Rajendiran, S.; Dotaniya, M.L.; Kundu, S. Impact of pigeon pea biochar on cadmium mobility in soil and transfer rate to leafy vegetable spinach. Environ. Monit. Assess. 2016, 188, 31. [CrossRef]

149. Bashir, S.; Hussain, Q.; Akmal, M.; Riaz, M.; Hu, H.; Ijaz, S.S.; Iqbal, M.; Abro, S.; Mehmood, S.; Ahmad, M. Sugarcane bagasse-derived biochar reduces the cadmium and chromium bioavailability to mash bean and enhances the microbial activity in contaminated soil. J. Soils Sediments 2018, 18, 874-886. [CrossRef]

150. Younis, U.; Malik, S.A.; Rizwan, M.; Qayyum, M.F.; Ok, Y.S.; Shah, M.H.R.; Rehman, R.A.; Ahmad, N. Biochar enhances the cadmium tolerance in spinach (Spinacia Oleracea) through modification of Cd uptake and physiological and biochemical attributes. Environ. Sci. Pollut. Res. 2016, 23, 21385-21394. [CrossRef] [PubMed]

151. Ramzani, P.M.A.; Shan, L.; Anjum, S.; Ronggui, H.; Iqbal, M.; Virk, Z.A.; Kausar, S. Improved quinoa growth, physiological response, and seed nutritional quality in three soils having different stresses by the application of acidified biochar and compost Plant Physiol. Biochem. 2017, 116, 127-138. [CrossRef]

152. Lebrun, M.; Macri, C.; Miard, F.; Hattab-Hambli, N.; Motelica-Heino, M.; Morabito, D.; Bourgerie, S. Effect of biochar amendments on $\mathrm{As}$ and $\mathrm{Pb}$ mobility and phytoavailability in contaminated mine technosols phytoremediated by salix. J. Geochemical Explor. 2017, 182, 149-156. [CrossRef]

153. Ogundiran, M.B.; Lawal, O.O.; Adejumo, S.A. Stabilisation of $\mathrm{Pb}$ in $\mathrm{Pb}$ smelting slag-contaminated soil by compost-modified biochars and their effects on maize plant growth. J. Environ. Prot. 2015, 6, 771. [CrossRef]

154. Trupiano, D.; Cocozza, C.; Baronti, S.; Amendola, C.; Vaccari, F.P.; Lustrato, G.; Di Lonardo, S.; Fantasma, F.; Tognetti, R.; Scippa, G.S. The effects of biochar and its combination with compost on lettuce (Lactuca Sativa L.) growth, soil properties, and soil microbial activity and abundance. Int. J. Agron. 2017, 2017. [CrossRef]

155. Doan, T.T.; Henry-des-Tureaux, T.; Rumpel, C.; Janeau, J.-L.; Jouquet, P. Impact of compost, vermicompost and biochar on soil fertility, maize yield and soil erosion in Northern Vietnam: A three year mesocosm experiment. Sci. Total Environ. 2015, 514, 147-154. [CrossRef]

156. Joseph, S.; Kammann, C.I.; Shepherd, J.G.; Conte, P.; Schmidt, H.-P.; Hagemann, N.; Rich, A.M.; Marjo, C.E.; Allen, J.; Munroe, P. Microstructural and associated chemical changes during the composting of a high temperature biochar: Mechanisms for nitrate, phosphate and other nutrient retention and release. Sci. Total Environ. 2018, 618, 1210-1223. [CrossRef]

157. Zhang, Z.; Dong, X.; Wang, S.; Pu, X. Benefits of organic manure combined with biochar amendments to cotton root growth and yield under continuous cropping systems in Xinjiang, China. Sci. Rep. 2020, 10, 1-10. [CrossRef]

158. Omara, P.; Aula, L.; Oyebiyi, F.B.; Eickhof, E.M.; Carpenter, J.; Raun, W.R. Biochar application in combination with inorganic nitrogen improves maize grain yield, nitrogen uptake, and use efficiency in temperate soils. Agronomy 2020, 10, 1241. [CrossRef]

159. Solaiman, Z.M.; Shafi, M.I.; Beamont, E.; Anawar, H.M. Poultry litter biochar increases mycorrhizal colonisation, soil fertility and cucumber yield in a fertigation system on sandy soil. Agriculture 2020, 10, 480. [CrossRef]

160. Ibrahim, M.M.; Tong, C.; Hu, K.; Zhou, B.; Xing, S.; Mao, Y. Biochar-fertilizer interaction modifies N-sorption, enzyme activities and microbial functional abundance regulating nitrogen retention in rhizosphere soil. Sci. Total Environ. 2020, $739,140065$. [CrossRef]

161. López-Ballesteros, A.; Senent-Aparicio, J.; Martínez, C.; Pérez-Sánchez, J. Assessment of future hydrologic alteration due to climate change in the Aracthos River Basin (NW Greece). Sci. Total Environ. 2020, 733, 139299. [CrossRef]

162. Fischer, B.M.C.; Manzoni, S.; Morillas, L.; Garcia, M.; Johnson, M.S.; Lyon, S.W. Improving agricultural water use efficiency with biochar-a synthesis of biochar effects on water storage and fluxes across scales. Sci. Total Environ. 2019, 657, 853-862. [CrossRef] [PubMed]

163. Fischer, B.; Manzoni, S.; Morillas, L.; Garcia, M.; Johnson, M.S.; Lyon, S.W. Can biochar improve agricultural water use efficiency? In Geophysical Research Abstracts; European Geosciences Union: Munich, Austria, 2019; Volume 21.

164. Agbna, G.H.D.; Dongli, S.; Zhipeng, L.; Elshaikh, N.A.; Guangcheng, S.; Timm, L.C. Effects of deficit irrigation and biochar addition on the growth, yield, and quality of tomato. Sci. Hortic. 2017, 222, 90-101. [CrossRef]

165. Aller, D.; Rathke, S.; Laird, D.; Cruse, R.; Hatfield, J. Impacts of fresh and aged biochars on plant available water and water use efficiency. Geoderma 2017, 307, 114-121. [CrossRef]

166. Haider, G.; Koyro, H.-W.; Azam, F.; Steffens, D.; Müller, C.; Kammann, C. Biochar but not humic acid product amendment affected maize yields via improving plant-soil moisture relations. Plant Soil 2015, 395, 141-157. [CrossRef]

167. Faloye, O.T.; Alatise, M.O.; Ajayi, A.E.; Ewulo, B.S. Effects of biochar and inorganic fertiliser applications on growth, yield and water use efficiency of maize under deficit irrigation. Agric. Water Manag. 2019, 217, 165-178. [CrossRef]

168. Bitarafan, Z.; Liu, F.; Andreasen, C. The effect of different biochars on the growth and water use efficiency of fenugreek (Trigonella Foenum-graecum L.). J. Agronom. Crop Sci. 2020, 206, 169-175. [CrossRef] 
169. Xia, L.; Xia, Y.; Li, B.; Wang, J.; Wang, S.; Zhou, W.; Yan, X. Integrating agronomic practices to reduce greenhouse gas emissions while increasing the economic return in a rice-based cropping system. Agric. Ecosyst. Environ. 2016, 231, 24-33. [CrossRef]

170. Huang, M.; Fan, L.; Chen, J.; Jiang, L.; Zou, Y. Continuous applications of biochar to rice: Effects on nitrogen uptake and utilization. Sci. Rep. 2018, 8, 1-9. [CrossRef] [PubMed]

171. Grutzmacher, P.; Puga, A.P.; Bibar, M.P.S.; Coscione, A.R.; Packer, A.P.; Andrade, C.A. Carbon stability and fertilizer induced $\mathrm{N}_{2} \mathrm{O}$ emissions mitigation in soil treated with biochar. Sci Total Env. 2018, 625, 1459-1466. [CrossRef]

172. Borchard, N.; Schirrmann, M.; Cayuela, M.L.; Kammann, C.; Wrage-Mönnig, N.; Estavillo, J.M.; Fuertes-Mendizábal, T.; Sigua, G.; Spokas, K.; Ippolito, J.A. Biochar, soil and land-use interactions that reduce nitrate leaching and $\mathrm{N}_{2} \mathrm{O}$ emissions: A meta-analysis. Sci. Total Environ. 2019, 651, 2354-2364. [CrossRef] [PubMed]

173. Edwards, J.D.; Pittelkow, C.M.; Kent, A.D.; Yang, W.H. Dynamic biochar effects on soil nitrous oxide emissions and underlying microbial processes during the maize growing season. Soil Biol. Biochem. 2018, 122, 81-90. [CrossRef]

174. Abbruzzini, T.F.; Davies, C.A.; Toledo, F.H.; Cerri, C.E.P. Dynamic biochar effects on nitrogen use efficiency, crop yield and soil nitrous oxide emissions during a tropical wheat-growing season. J. Environ. Manag. 2019, 252, 109638. [CrossRef]

175. Sun, H.; Zhang, H.; Shi, W.; Zhou, M.; Ma, X. Effect of biochar on nitrogen use efficiency, grain yield and amino acid content of wheat cultivated on saline soil. Plant Soil Environ. 2019, 65, 83-89. [CrossRef]

176. Abbas, S.; Javed, M.T.; Ali, Q.; Chaudhary, H.J.; Rizwan, M. Alteration of plant physiology by the application of biochar for remediation of organic pollutants. Handb. Bioremediat. 2021, 475-492. [CrossRef]

177. Khan, K.Y.; Ali, B.; Cui, X.; Feng, Y.; Yang, X.; Stoffella, P.J. Impact of different feedstocks derived biochar amendment with cadmium low uptake affinity cultivar of pak choi (Brassica Rapa Ssb. Chinensis L.) on phytoavoidation of Cd to reduce potential dietary toxicity. Ecotoxicol. Environ. Saf. 2017, 141, 129-138. [CrossRef]

178. Rafique, M.; Ortas, I.; Rizwan, M.; Chaudhary, H.J.; Gurmani, A.R.; Hussain Munis, M.F. Residual effects of biochar and phosphorus on growth and nutrient accumulation by maize (Zea Mays L.) amended with microbes in texturally different soils. Chemosphere 2020, 238. [CrossRef] [PubMed]

179. Qian, Z.H.U.; Kong, L.; Shan, Y.; Yao, X.; Zhang, H.; Xie, F.; Xue, A.O. Effect of biochar on grain yield and leaf photosynthetic physiology of soybean cultivars with different phosphorus efficiencies. J. Integr. Agric. 2019, 18, $2242-2254$.

180. Ali, S.; Rizwan, M.; Noureen, S.; Anwar, S.; Ali, B.; Naveed, M.; Abd_Allah, E.F.; Alqarawi, A.A.; Ahmad, P. Combined use of biochar and zinc oxide nanoparticle foliar spray improved the plant growth and decreased the cadmium accumulation in rice (Oryza Sativa L.) plant. Environ. Sci. Pollut. Res. 2019, 26, 11288-11299. [CrossRef]

181. Kamran, M.; Malik, Z.; Parveen, A.; Zong, Y.; Abbasi, G.H.; Rafiq, M.T.; Shaaban, M.; Mustafa, A.; Bashir, S.; Rafay, M. Biochar alleviates cd phytotoxicity by minimizing bioavailability and oxidative stress in pak choi (Brassica Chinensis L.) cultivated in Cd-polluted soil. J. Environ. Manag. 2019, 250, 109500. [CrossRef]

182. Raboin, L.-M.; Razafimahafaly, A.H.D.; Rabenjarisoa, M.B.; Rabary, B.; Dusserre, J.; Becquer, T. Improving the fertility of tropical acid soils: Liming versus biochar application? A long term comparison in the highlands of Madagascar. Field Crop. Res. 2016, 199, 99-108. [CrossRef]

183. Agegnehu, G.; Bass, A.M.; Nelson, P.N.; Muirhead, B.; Wright, G.; Bird, M.I. Biochar and biochar-compost as soil amendments: Effects on peanut yield, soil properties and greenhouse gas emissions in tropical North Queensland, Australia. Agric. Ecosyst. Environ. 2015, 213, 72-85. [CrossRef]

184. Xu, C.-Y.; Bai, S.H.; Hao, Y.; Rachaputi, R.C.N.; Xu, Z.; Wallace, H.M. Peanut shell biochar improves soil properties and peanut kernel quality on a red ferrosol. J. Soils Sediments 2015, 15, 2220-2231. [CrossRef]

185. Agegnehu Jenberu, G. Biochar, Compost and Biochar-Compost: Effects on Crop Performance, Soil Quality and Greenhouse Gas Emissions in Tropical Agricultural Soils; James Cook University: Douglas, QLD, Australia, 2017.

186. Zhang, D.; Pan, G.; Wu, G.; Kibue, G.W.; Li, L.; Zhang, X.; Zheng, J.; Zheng, J.; Cheng, K.; Joseph, S. Biochar helps enhance maize productivity and reduce greenhouse gas emissions under balanced fertilization in a rainfed low fertility inceptisol. Chemosphere 2016, 142, 106-113. [CrossRef] [PubMed]

187. Anyanwu, I.N.; Alo, M.N.; Onyekwere, A.M.; Crosse, J.D.; Nworie, O.; Chamba, E.B. Influence of biochar aged in acidic soil on ecosystem engineers and two tropical agricultural plants. Ecotoxicol. Environ. Saf. 2018, 153, 116-126. [CrossRef]

188. Khorram, M.S.; Zhang, G.; Fatemi, A.; Kiefer, R.; Mahmood, A.; Jafarnia, S.; Zakaria, M.P.; Li, G. Effect of walnut shell biochars on soil quality, crop yields, and weed dynamics in a 4-year field experiment. Environ. Sci. Pollut. Res. 2020, 27, 1-11.

189. Zhu, Q.; Peng, X.; Huang, T. Contrasted effects of biochar on maize growth and $\mathrm{n}$ use efficiency depending on soil conditions. Int. Agrophysics 2015, 29, 257-266. [CrossRef]

190. Zheng, H.; Liu, B.; Liu, G.; Cai, Z.; Zhang, C. Potential toxic compounds in biochar: Knowledge gaps between biochar research and safety. In Biochar from Biomass and Waste; Elsevier: Amsterdam, The Netherlands, 2019; pp. 349-384.

191. Lipczynska-Kochany, E. Effect of climate change on humic substances and associated impacts on the quality of surface water and groundwater: A review. Sci. Total Environ. 2018, 640, 1548-1565. [CrossRef] [PubMed]

192. Elliston, T.; Oliver, I.W. Ecotoxicological assessments of biochar additions to soil employing earthworm species eisenia fetida and lumbricus terrestris. Environ. Sci. Pollut. Res. 2019, 27, 1-9. [CrossRef] [PubMed] 